\title{
Oxytocin Regulates Stress-Induced Crf Gene Transcription through CREB-Regulated Transcription Coactivator 3
}

\author{
Benjamin Jurek, ${ }^{1}$ David A. Slattery, ${ }^{1}$ Yuichi Hiraoka, ${ }^{2}$ Ying Liu, ${ }^{3}{ }^{-K a t s u h i k o ~ N i s h i m o r i, ~}{ }^{2}$ Greti Aguilera, ${ }^{3}$ \\ Inga D. Neumann, ${ }^{1 \star}$ and Erwin H. van den Burg ${ }^{1 \star}$ \\ 'Department of Behavioral and Molecular Neurobiology, University of Regensburg, Regensburg 93040, Germany, ${ }^{2}$ Laboratory of Molecular Biology, \\ Tohoku University Graduate School of Agricultural Science, Aoba-ku, Sendai-city 981-8555, Miyagi-pref, Japan, and 3 Section on Endocrine Physiology, \\ Program on Developmental Endocrinology and Genetics, Eunice Kennedy Shriver Institute of Child Health and Human Development, NIH, Bethesda, \\ Maryland 20892
}

The major regulator of the neuroendocrine stress response in the brain is corticotropin releasing factor (CRF), whose transcription is controlled by CREB and its cofactors CRTC2/3 (TORC2/3). Phosphorylated CRTCs are sequestered in the cytoplasm, but rapidly dephosphorylated and translocated into the nucleus following a stressful stimulus. As the stress response is attenuated by oxytocin (OT), we tested whether OT interferes with CRTC translocation and, thereby, Crfexpression. OT ( $1 \mathrm{nmol}$, i.c.v.) delayed the stress-induced increase of nuclear CRTC3 and $\mathrm{Cr} f$ hnRNA levels in the paraventricular nucleus of male rats and mice, but did not affect either parameter in the absence of the stressor. The increase in Crf hnRNA levels at later time points was parallel to elevated nuclear CRTC2/3 levels. A direct effect of $\mathrm{Thr}^{4} \mathrm{Gly}^{7}$-OT (TGOT) on CRTC3 translocation and Crf expression was found in rat primary hypothalamic neurons, amygdaloid (Ar-5), hypothalamic (H32), and human neuroblastoma (Be(2)M17) cell lines. CRTC3, but not CRCT2, knockdown using siRNA in Be(2)M17 cells prevented the effect of TGOT on CrfhnRNA levels. Chromatin-immunoprecipitation demonstrated that TGOT reduced CRTC3, but not CRTC2, binding to the Crf promoter after $10 \mathrm{~min}$ of forskolin stimulation. Together, the results indicate that OT modulates CRTC3 translocation, the binding of CRTC3 to the Crf promoter and, ultimately, transcription of the Crf gene.

Key words: Crf; CRTC3/TORC3; intracellular signaling; oxytocin receptor; stress response

\section{Significance Statement}

The neuropeptide oxytocin has been proposed to reduce hypothalamic-pituitary-adrenal (HPA) axis activation during stress. The underlying mechanisms are, however, elusive. In this study we show that activation of the oxytocin receptor in the paraventricular nucleus delays transcription of the gene encoding corticotropin releasing factor $(\mathrm{Crf})$, the main regulator of the stress response. It does so by sequestering the coactivator of the transcription factor CREB, CRTC3, in the cytosol, resulting in reduced binding of CRTC3 to the $C r f$ gene promoter and subsequent $C r f$ gene expression. This novel oxytocin receptor-mediated intracellular mechanism might provide a basis for the treatment of exaggerated stress responses in the future.

\section{Introduction}

The neuropeptide corticotropin releasing factor (CRF), synthesized in the hypothalamic paraventricular nucleus (PVN), is the

\footnotetext{
Received April 3, 2014; revised July 20, 2015; accepted July 23, 2015.

Author contributions: B.J., D.A.S., G.A., I.D.N., and E.H.v.d.B. designed research; B.J., D.A.S., Y.H., Y.L., G.A., and E.H.v.d.B. performed research; K.N. contributed unpublished reagents/analytic tools; B.J., D.A.S., Y.H., G.A., I.D.N., and E.H.v.d.B. analyzed data; B.J., D.A.S., G.A., I.D.N., and E.H.v.d.B. wrote the paper.

This work was supported by the German Research Foundation (I.D.N., E.v.d.B.), the Boehringer Ingelheim Foundation (B.J.), the Intramural Research Program, NICHD (G.A.), and SRPBS, Japan (MEXT; Y.H., K.N.). The funders had no role in study design, data collection and analysis, decision to publish, or preparation of the paper.

The authors declare no competing financial interests.

*I.D.N. and E.H.v.d.B. share last authorship.

Correspondence should be addressed to Inga D. Neumann, University of Regensburg, Regensburg 93040, Germany. E-mail: inga.neumann@biologie.uni-regensburg.de.
}

main activator of the hypothalamo-pituitary-adrenal (HPA) axis during stress. Following its release into portal vessels of the median eminence, CRF stimulates the release of ACTH from the pituitary gland. CRF-producing neurons are under negative feedback by glucocorticoids, thus preventing the detrimental effects of long-term excessive HPA axis activity. CRF cells are further regulated by other factors during stress, including the neuropeptide oxytocin (OT; Neumann et al., 2000b; Windle et al., 2004). Known for its role in reproduction in the periphery, central OT via its OT receptor (OTR) promote prosocial behavior and dampen HPA axis activity (Donaldson and Young, 2008; Neu- 


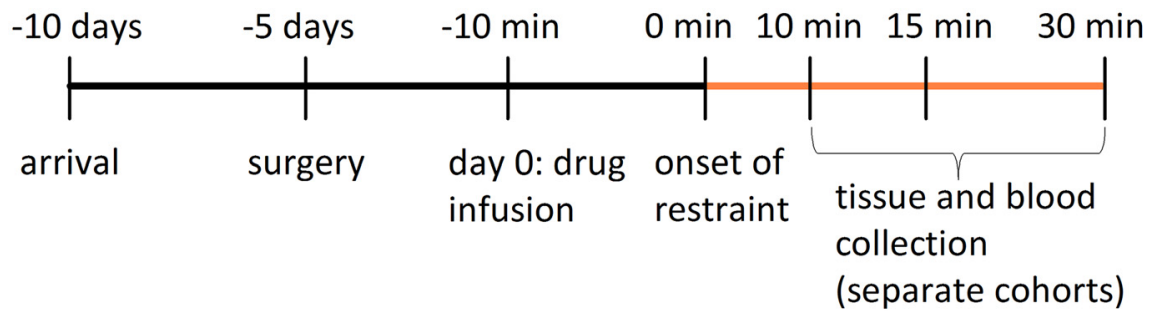

Figure 1. Time course of the in vivo experiments conducted.

ular infusion into the vicinity of the PVN was performed under isoflurane anesthesia and semisterile conditions. Following surgery, the animals received a subcutaneous injection of antibiotics ( $0.03 \mathrm{ml}$ enrofloxacin; $100 \mathrm{mg} / 1 \mathrm{ml}$ Baytril, Bayer) and allowed to recover for at least $6 \mathrm{~d}$. Animals were single-housed after surgery and rats were handled daily to habituate them to the central infusion procedure to avoid nonspecific stress responses during the experiment. Mice were left undisturbed in their home cage.

To determine the effect of OT on hypothamann and Landgraf, 2012). Elevated levels of endogenous OT, as observed during the peripartum period (Van Tol et al., 1988; Neumann et al., 1993; Hillerer et al., 2011), as well as chronic infusion of synthetic OT (Windle et al., 2004), reduce stressinduced ACTH response in rats. However, earlier studies have reported potentiating effects of peripheral OT on stress-induced ACTH release (Gibbs et al., 1984; Petersson et al., 1999; Ondrejcakova et al., 2010). Although there is evidence that OT is released within the PVN in response to acute stress (Engelmann et al., 1999), it is unknown whether such locally released OT directly alters the activity of CRF cells during stress.

One of the early hallmarks of CRF cell activity during stress is increased Crf gene transcription via a cAMP/PKA-dependent mechanism; presumably to replenish protein stores within the cells (Aguilera and Liu, 2012). The downstream binding of phosphorylated cAMP-responsive element binding protein (pCREB) to a cAMP-responsive element (CRE) in the promoter is accompanied by binding of a CREB coactivator, CREBregulated transcriptional coactivators (CRTC1-3) to CREB. Under basal conditions, CRTC is phosphorylated and bound to the scaffolding protein 14-3-3 in the cytoplasm. Following its dephosphorylation, CRTC translocates to the nucleus, where it binds CREB via its bZIP domain acting as a coactivator for the recruitment of $\mathrm{CBP} / \mathrm{p} 300$ to the $C r f$ promoter for gene transcription to commence (Conkright et al., 2003; Liu et al., 2011). As OT was shown to phosphorylate CREB in the hippocampus (Tomizawa et al., 2003), we hypothesized that OT regulates Crf expression by controlling the translocation and, therefore, nuclear availability of CRTC2 and CRTC3, which play an important role in the regulation of Crf gene transcription (Liu et al., 2011), at least in vitro. In the present study we found that OT delays stressinduced Crf gene transcription in the PVN through inhibition of CRTC3 translocation, and subsequent CRTC3, but not CRTC2, binding to the Crf promoter.

\section{Materials and Methods}

\section{Animals}

Adult male and female Wistar rats, adult male and female C57BL/6J mice (Charles River Laboratories, 250-300 g and 25-30 g, respectively, at the beginning of the experiment), and transgenic male and female C57BL/6J OTR-Venus reporter mice (Tohoku University Japan; Yoshida et al., 2009) were housed in separate rooms under standard laboratory conditions in groups of $3-4\left(12 \mathrm{~h} \mathrm{light/dark} \mathrm{cycle,} 22-24^{\circ} \mathrm{C}\right.$, lights on at 06:00 $\mathrm{h}$, food and water ad libitum). All animal experiments were performed between 08:00 and 11:00 A.M., in accordance with the Guide for the Care and Use of Laboratory Animals by the National Institutes of Health, and were approved by the government of the Oberpfalz, Germany, and the Institutional Animal Care and Use Committee of Tohoku University.

Stereotaxic implantation of an intracerebroventricular guide cannula in rats and mice and effects of intracerebroventricular infusion of OT or TGOT on protein phosphorylation and anxiety Stereotaxic implantation of a guide cannula above the third ventricle (rats) or the lateral ventricle (mice) for subsequent intracerebroventric- lamic Crf expression and CRTC translocation, vehicle, OT (SigmaAldrich, rats $1 \mathrm{nmol} / 2 \mu \mathrm{l}$ ), or $\mathrm{Thr}^{4}$ Gly $^{7}$-OT (TGOT; Bachem, rats 1 $\mathrm{nmol} / 2 \mu \mathrm{l}$; mice $0.5 \mathrm{nmol} / 2 \mu \mathrm{l}$ ) were infused through an intracerebroventricular infusion cannula (stainless steel, rats: $28 \mathrm{G}, 14.7 \mathrm{~mm}$ long; mice $25 \mathrm{G}, 10.7 \mathrm{~mm}$ long) inserted into an indwelling intracerebroventricular guide cannula (rats $23 \mathrm{G}, 12 \mathrm{~mm}$ long; mice $21 \mathrm{G}, 8 \mathrm{~mm}$ long), stereotaxically implanted $2 \mathrm{~mm}$ above the third (rats) or lateral (mice) ventricle (rats AP: $+0.9 \mathrm{~mm}$ bregma, ML: $-1.2 \mathrm{~mm}$ lateral, DV: $+5 \mathrm{~mm}$ below the surface of the skull, angle: $10^{\circ}$; mice: $\mathrm{AP}+0.2 \mathrm{~mm}, \mathrm{ML}+1.0$ mm, V+1.4 mm; Paxinos and Watson, 1998; Baird et al., 2008; Roy et al., 2011) as described previously (Toth et al., 2012).

The effectiveness of intracerebroventricular OT or TGOT was assessed by measuring the phosphorylation of CaMKII and MEK1/2 in the PVN, which are two known markers of OTR activation (Jurek et al., 2012; and unpublished observation). Although infusion of OT directly into the $\mathrm{PVN}$, or locally released endogenous OT, is anxiolytic, infusion of OT into the lateral ventricle of rats and mice is not (Waldherr and Neumann, 2007; Zoicas et al., 2014). Whether OT is anxiolytic, when infused into the third ventricle, i.e., in the immediate vicinity of the PVN, has not been addressed before. Therefore, we tested whether our infusion procedure affects anxiety-like behavior, using the light/dark box (LDB) test (see below).

\section{Light/dark box}

The LDB was performed 10 min after intracerebroventricular infusion of either OT or TGOT as previously described (Slattery and Neumann, 2010; Jurek et al., 2012). Briefly, LDB setup consisted of two compartments; one lit compartment $(40 \times 50 \mathrm{~cm}, 350$ lux, light box $)$ and one dark compartment $(40 \times 30 \mathrm{~cm}, 70$ lux $)$. The floors in each compartment were divided into squares $(10 \times 10 \mathrm{~cm})$ and the compartments were connected via a small opening $(7.5 \times 7.5 \mathrm{~cm})$. Rats were placed in the light compartment, and measurements of anxiety and locomotor activity (line crosses, time spent in each compartment, rearings, latency to first dark compartment entry, latency to first re-entry in light compartment, and total entries into light compartment) during the 5 min test were assessed online via a camera located above the box, by an observer blind to treatment.

Effects of intracerebroventricular OT or TGOT on stress-induced Crf gene expression and CRTC2/3 translocation

To analyze the influence of OT or TGOT on basal and stress-induced Crf expression and CRTC translocation in the PVN, four groups of rats were used in separate cohorts: (1) intracerebroventricular vehicle (Ringer)/no stress group (Veh-NS), (2) intracerebroventricular OT (TGOT)/no stress group (OT-NS/TGOT-NS), (3) intracerebroventricular vehicle/restraint stress group (Veh-RS), and (4) intracerebroventricular OT (TGOT)/restraint stress group (OT-RS/TGOT-RS). The time course of the experiment is depicted in Figure 1. OT and TGOT are equally effective at the concentration applied ( $1 \mathrm{nmol}$ in $2 \mu \mathrm{l}$; Blume et al., 2008; Lukas et al., 2011; Viviani et al., 2011; Jurek et al., 2012) and have a similar affinity for the OTR (Manning et al., 2008). TGOT was used in some of the experiments, outlined in detail below, to exclude the contribution of the vasopressin receptors to the observed effects as TGOT has minimal affinity for the V1a receptor (Manning et al., 2008). The drugs, or their vehicle, were infused $10 \mathrm{~min}$ before the restraint stress procedure, and the animals were returned to their home cage after infusion. Then, rats were 
restrained for 10, 15, or $30 \mathrm{~min}$ in a Plexiglas cylinder (12 cm diameter) with ventilation holes. The nonstressed controls, which remained in their home cage, were time-matched to accommodate for the time of the stressor. Immediately after the respective restraint period, stressed and control rats were decapitated, trunk blood was collected and brains were rapidly removed, frozen on dry-ice, and stored at $-80^{\circ} \mathrm{C}$ until cryosectioning for Crf expression or CRTC translocation analysis. The brains were cut at a thickness of $250 \mu \mathrm{m}$, and the PVN was microdissected with a tissue puncher (Fine Science Tools, $1.8 \mathrm{~mm}$ diameter; Jurek et al., 2012), placed in $1.5 \mathrm{ml}$ microcentrifuge tubes on dry ice and stored at $-80^{\circ} \mathrm{C}$ until RNA extraction using TriFast Gold (PeqLab) according to the manufacturer's protocol (see below). For CRTC translocation analysis, microdissected PVNs were directly transferred to lysis buffer (see below). In addition, cortical, hippocampal, and septal tissue served as control for brain region-specific effects of stress and OT. The restraint stress protocol for male C57BL/6J mice was similar to that for rats with minor modifications. Mice were restraint using $50 \mathrm{ml}$ Falcon tubes (BD Falcon) with ventilation holes for $10 \mathrm{~min}$, immediately anesthetized, decapitated, and the brains removed for protein isolation from hypothalamic tissue.

\section{Crf/OTR colocalization}

Transgenic male OTR-Venus reporter mice were restrained for $30 \mathrm{~min}$, returned to their home cage for $90 \mathrm{~min}$, and then killed by cervical dislocation. This protocol has been previously shown to induce high levels of Crf mRNA (Aguilera and Liu, 2012).

Unstressed and stressed male, as well as pregnant female mice, were deeply anesthetized by tribromoethanol, and the brains from male mice and embryonic day (E) 18 embryos from females were immediately dissected out. The brains were postfixed with $4 \%$ paraformaldehyde (PFA)/ phosphate buffer overnight, and cryoprotected in 30\% sucrose. Tissues were embedded in OCT compound (Tissue-Tek) and cut in $30-\mu \mathrm{m}-$ thick sagittal sections with a cryostat (Leica, CM1950). Sections were individually mounted on slides and processed for in situ hybridization (ISH) to visualize the expression of $C r f$. Nonradioactive ISH was performed as previously described (Assimacopoulos et al., 2003) with minor modifications. Glass slides with sections were fixed by $4 \%$ PFA. Sections were then permeabilized by detergents ( $1 \%$ Nonidet P- $40,1 \%$ SDS, $0.5 \%$ deoxycholate), and hybridized with digoxigenin-labeled probes (Roche) at $70^{\circ} \mathrm{C}$ overnight. The cRNA probe sequence was cloned from embryonic day 18 mouse whole brain cDNA by using specific primers $\left(5^{\prime}-\right.$ GAGAGAATTCTAGAGCCTGTCTTGTCTGTG-3' and 5' -GAGACTC GAGAGCATGGGCAATACAAATAA-3'). Excess probes were washed out and sections were blocked with sheep serum and incubated with solution containing alkaline phosphatase-conjugated with digoxigeninlabeled antibodies (Roche). The color was developed with Fastred (Roche) according to the manufacturer's instructions. For doubleimmunostaining, sections were then incubated with anti-GFP antibody (Santa Cruz Biotechnology, sc-8334, rabbit polyclonal, 1:200), which recognizes the Venus protein, as it is a modified version of GFP (Yoshida et al., 2009), overnight at $4^{\circ} \mathrm{C}$. The sections were rinsed and incubated in species-specific secondary antibodies, which were tagged with AlexaFluor 488 (Molecular Probes). Images were taken with a confocal laser microscope (Zeiss LSM780).

\section{Cell culture and stimulation}

Primary hypothalamic neurons. Primary cultures of hypothalamic neurons were prepared from fetal Wistar rats, E18, by collagenase dispersion and plated in six-well plates at $37^{\circ} \mathrm{C} / 5 \% \mathrm{CO}_{2}$ as previously described (Liu et al., 2008). After $24 \mathrm{~h}$ in the presence of serum, cultures were maintained for 8 additional days in neurobasal medium containing B27 supplement (both Life Technologies, Invitrogen). Cytosine arabinoside (Sigma-Aldrich) was added to a final concentration of $5 \mu \mathrm{M}$ from day 4 onward to prevent glial cell proliferation. On day 10, growth medium was replaced by supplement-free neurobasal medium containing $0.1 \%$ BSA. After $1 \mathrm{~h}$ of preincubation in this medium, cells were incubated with $\left(\mathrm{FSK}^{+}\right)$or without $\left(\mathrm{FSK}^{-}\right)$the adenylate cyclase stimulator forskolin (FSK; $1 \mu \mathrm{M}$, Sigma-Aldrich) in presence $\left(\mathrm{TGOT}^{+}\right.$) or in absence $\left(\mathrm{TGOT}^{-}\right)$of the specific OTR agonist TGOT (10 nM, Bachem) for the periods of time indicated in Results. Following incubation, cells were harvested and RNA was isolated as described below.
Hypothalamic H32 and amygdaloid Ar 5 cells. The hypothalamic rat cell line H32 (Mugele et al., 1993) and the amygdaloid rat cell line Ar5 (Dalwadi and Uht, 2013) were cultured in DMEM (Life Technologies) containing $10 \%$ fetal bovine serum, $10 \%$ horse serum, and $1 \%$ penicillin/ streptomycin (Life Technologies) at $37^{\circ} \mathrm{C}$ and $5 \% \mathrm{CO}_{2}$. Before the experiments, the cells were transferred to $100 \mathrm{~mm}$ plates at a density of $3 \times 10^{6}$ cells per plate. Twenty-four hours later, the medium was changed to serum-free medium containing $0.1 \%$ BSA for $2 \mathrm{~h}$. To determine the signaling pathways mediating the effects of OT, cells were incubated as described above with $\left(\mathrm{TGOT}^{+}\right.$) or without $\left(\mathrm{TGOT}^{-}\right.$) $\mathrm{TGOT}^{-}$ $(10 \mathrm{nM})$, in the presence $\left(\mathrm{FSK}^{+}\right)$or absence $\left(\mathrm{FSK}^{-}\right)$of FSK $(1 \mu \mathrm{M} \mathrm{H} 32$, $50 \mu \mathrm{M}$ Ar-5). After incubation for the time periods indicated in the results section and figure legends, cytoplasmic and nuclear proteins were extracted for Western blot analysis for CRTC2/3 and pCREB levels as described below.

Human Be(2)-M17 cells. The human neuroblastoma cell line Be(2)M17 (European Collection of Cell Cultures, no. 95011816) was cultured in DMEM/F12 (1:1; Invitrogen) containing L-glutamine, $2.4 \mathrm{~g} / \mathrm{L}$ sodium bicarbonate, $15 \%$ heat-inactivated fetal bovine serum (Invitrogen), $1 \%$ nonessential amino acids (Invitrogen), and $0.1 \mathrm{mg} / \mathrm{ml}$ gentamycin (Invitrogen $15750-060$ ) at $37^{\circ} \mathrm{C}$ and $5 \% \mathrm{CO}_{2}$. Three days before the experiment, the cells were differentiated to neurons by adding retinoic acid (Sigma-Aldrich) to a final concentration of $5 \mu \mathrm{m}$. On the day of experiment, cells were incubated in serum-free DMEM/F12 (+ 0.1\% BSA) for $2 \mathrm{~h}$ to reduce basal activation of gene transcription initiated by serum components. The TGOT (10 nM), des-Gly- $\mathrm{NH}_{2} \mathrm{~d}\left(\mathrm{CH}_{2}\right)_{5}\left[\mathrm{Tyr}(\mathrm{Me})^{2} \mathrm{Thr}^{4}\right]$-OVT (referred to as OTA, $1 \mu \mathrm{M}$; Manning et al., 1989), and FSK (50 $\mu \mathrm{M})$ stimulation and RNA isolation protocols of the $\mathrm{Be}(2)-\mathrm{M} 17$ cells were similar to those described for $\mathrm{H} 32$ cells.

\section{$R N A$ isolation and $q P C R$}

Punched rat PVN tissue from the stress experiments was treated with 1 $\mathrm{ml}$ TriFast Gold (PeqLab), vortexed to homogenize tissue, and RNA isolated according to the protocol provided by the manufacturer with some modifications. Briefly, the aqueous supernatant obtained from chloroform precipitation with TriFast was transferred to an RNeasy Mini Kit (Qiagen) column, washed, treated with RNase-free DNase (according to the manufacturer's protocol, Qiagen), washed, and eluted with nuclease-free water. RNA content was determined with the aid of a NanoDrop photospectrometer (PeqLab; Liu and Aguilera, 2009).

To isolate RNA from the stimulated cells, the medium was aspirated off, and $1 \mathrm{ml}$ of TriFast Gold Reagent (PeqLab) was added to the six-well plates (primary cells) or $10 \mathrm{~cm}$ culture dishes (Be(2)-M17 cells). The lysed cells were scraped off using a cell scraper and collected in RNasefree $1.5 \mathrm{ml}$ tubes. RNA was isolated as described for brain punches.

Three hundred nanograms of total RNA per sample were used for reverse transcription into cDNA using Super Script III First strand Synthesis System for RT-PCR (Invitrogen). Relative quantification of Crf (NM_000756.1) hnRNA levels was performed using SYBR Green (QuantiFast Qiagen), ribosomal protein L13A (Rpl13A, NR_073024), and cyclophilin A (CycA, NM_021130) as housekeeping genes (Bonefeld et al., 2008; Table 1). Specificity of the qPCR was assured by omitting reverse transcription and by using $\mathrm{ddH}_{2} \mathrm{O}$ as template. As the results obtained using Rpl13A and CycA yielded similar results, only those for Rpl13A are shown. The PCR protocol consisted of an initial denaturation step of 5 min at $95^{\circ} \mathrm{C}$, followed by 50 cycles of denaturation at $95^{\circ} \mathrm{C}$ for $10 \mathrm{~s}$, and annealing/extension at $60^{\circ} \mathrm{C}$ for $45 \mathrm{~s}$. At the end of the protocol, a melting curve was generated and PCR products were analyzed by agarose gel electrophoresis to confirm the specificity of the primers. All samples were run in triplicate.

\section{Western blotting}

Single hypothalamic punches containing the PVN from the stress experiments were lysed in $500 \mu \mathrm{l}$ of lysis buffer included in the nuclear extraction kit (Active Motif) that was used to isolate the proteins from both the cytosolic and nuclear fractions. $\mathrm{Be}(2)-\mathrm{M} 17$ cells were lysed according to Active Motif's protocol for cell lysis. Nuclear extracts from $\mathrm{H} 32$ cells and Ar 5 cells were prepared using NE-PER Nuclear and Cytoplasmic Extraction Reagent (Pierce) according to the manufacturer's protocol. Western 
Table 1. Primer sequences with corresponding amplicon size and species

\begin{tabular}{|c|c|c|c|}
\hline Target name & Sequence & Species & Amplicon size, bp \\
\hline Rpl13A forw & 5'ACAAGAAAAAGCGGATGGTG3' & Rat & 167 \\
\hline Rpl13A rev & 5'TTCCGGTAATGGATCTTTGC3' & Rat & \\
\hline CycA forw & 5'AGCACTGGGGAGAAAGGATT3' & Rat & 248 \\
\hline CycA rev & 5'AGCCACTCAGTCTTGGCAGT3' & Rat & \\
\hline Crf hnRNA forw & 5' TCAATCCAATCTGCCACTCA3' & Rat & 154 \\
\hline CrfhnRNA rev & 5' TAAGCTATTCGCCCGCTCTA3' & Rat & \\
\hline Crf hnRNA forw & 5'AAGACAACCTCCAGAGAAAG3' & Human & 324 \\
\hline CrfhnRNA rev & 5'CATCCCAGCTACTATTGTAATC ${ }^{\prime}$ & Human & \\
\hline CrfmRNA forw & 5'GCATGCACAAAGTGTGTTTC3' & Rat & 194 \\
\hline CrfmRNA rev & 5'AAACAACTGGGTGACTTCCA3' & Rat & \\
\hline Rpl13A forw & 5'TGGCTAAACAGGTACTGCTGG3' & Human & 284 \\
\hline Rpl13A rev & 5'CCGCTTTTTCTTGTCGTAGGG3' & Human & \\
\hline CrfChIP forw & 5'AGTCATAAGAAGCCCTTCCA-3' & Human & 92 \\
\hline CrfChIP rev & 5'CAACACTGAATCTCACATCCA-3' & Human & \\
\hline CRTC2 siRNA & $5^{\prime}$-CUAUAGUCCUGCCUACUUAtt-3' & Human & \\
\hline CRTC3 siRNA & $5^{\prime}-\mathrm{GCACAUCAAGGUUUCAGCAtt-3^{ \prime }}$ & Human & \\
\hline
\end{tabular}

forw, Forward; rev, reverse.

Table 2. Antibodies used for Western blotting with optimal dilution factor and diluent

\begin{tabular}{llll}
\hline Target & Company & Dilution & Diluent \\
\hline Anti pMEK1/2 & Cell Signaling Technology & $1: 2000$ & 5\% BSA \\
Anti-pCaMKII & Abcam & $1: 200$ & $5 \%$ Milk powder \\
Anti-CRTC2 & Calbiochem/EDM & $1: 12.000$ & TBS-T \\
Anti-CRTC3 & Abcam ab91654 & $1: 2000$ & TBS-T \\
Anti-phospho-CREB & Upstate Millipore & $1: 1000$ & $5 \%$ Milk powder \\
Anti-CREB & Cell Signaling Technology \#9197 & $1: 1000$ & $5 \%$ Milk powder \\
Anti-lamin A/C & Active Motif \#39287 & $1: 5000$ & TBS-T \\
Anti- $\beta$ tubulin & Cell Signaling Technology \#2146 & $1: 1000$ & $5 \%$ Milk powder \\
Anti-Ras & Abcam ab52939 & $1: 5000$ & TBS-T \\
Anti-HDAC1 & Santa Cruz Biotechnology sc6298 & $1: 1000$ & TBS-T \\
\hline
\end{tabular}

blot analysis was used to detect CRTC2 and 3 translocation and CREB phosphorylation as previously described (Liu et al., 2008), using Lamin A, $\beta$-tubulin, Ras, and histone deacetylase 1 as loading controls. For CREB, phosphorylated CREB ( $\mathrm{pCREB}$ ), and CRTC3, $15 \mu \mathrm{g}$ of cytoplasmic or nuclear extract were loaded and separated in a $6 \%$ Tris-glycine gel (Invitrogen). To detect CRTC2 from Be(2)-M17 lysates, $30 \mu \mathrm{g}$ of protein were loaded onto the gel. Equal amounts of protein from PVN punches were loaded onto SDS gels for analysis (Table 2).

The primary antibodies were diluted in Tris-buffered saline supplemented with $0.1 \%$ Tween 20 (TBS-T, Sigma-Aldrich), or 5\% fat-free dry milk powder in TBS. After blocking the membrane for $1 \mathrm{~h}$ in $5 \%$ milk powder or BSA, the blots were incubated with the primary antibodies at the respective dilution overnight at $4^{\circ} \mathrm{C}$ with gentle agitation. After washing and incubating with the appropriate horseradish peroxidase-labeled secondary antibody, immunoreactive bands were visualized using enhanced chemiluminescence plus detection system and film exposure (Liu et al., 2008), or with the ChemiDoc XRS + Imager (Bio-Rad). The intensity of the bands on the film was quantified using ImageJ (NIH). Images obtained with the ChemiDoc XRS + were analyzed with the accompanying software. Following imaging, blots were stripped with a mild stripping solution (Millipore), or $0.2 \mathrm{~N} \mathrm{NaOH}$ and assayed for HDAC1, Lamin A, total CREB, Ras, or $\beta$-tubulin as loading controls.

To control for cross-contamination of cytoplasmic and nuclear fractions, blots were reprobed with nuclear TATA-box binding protein and cytoplasmic anti-Ras antibody. Negligible cross-contamination between fractions was detected.

\section{siRNA transfection}

$\mathrm{Be}(2)$-M17 cells $\left(4 \times 10^{6}\right.$ cells) plated in $100 \times 20 \mathrm{~mm}$ cell culture dishes (Sarstedt) were transfected with $33 \mathrm{~nm}$ small interfering RNA (siRNA) and Lipofectamine RNAiMAX Reagent (Invitrogen), diluted in OptiMEM (Invitrogen) to inhibit CRTC2 and CRTC3 synthesis. siRNA specific for CRTC2, CRTC3, and the negative control Silencer no. 5 were purchased from Ambion/Life Technologies. The human oligonucleotide sequences were $5^{\prime}$-CUAUAGUCCUGCCUACUUAtt-3' (sense) for CRTC2 (NM_181715), and 5'-GCACAUCAAGGUUUCAGCAtt-3' (sense) for CRTC3 (NM_022769; Table 1). After $12 \mathrm{~h}$, transfection medium was removed and replaced by DMEM/F12 (supplemented with $0.1 \%$ BSA, sterile filtered) for $2 \mathrm{~h}$. The cells were then stimulated as described above with $\left(\mathrm{FSK}^{+}\right)$or without $\left(\mathrm{FSK}^{-}\right) \mathrm{FSK}(50 \mu \mathrm{M})$ in the presence $\left(\mathrm{TGOT}^{+}\right)$or absence $\left(\mathrm{TGOT}^{-}\right)$of TGOT $(10 \mathrm{nM})$ for $1 \mathrm{~h}$, and gene and protein expression were analyzed as described above. Verification of knockdown was performed by RT-qPCR for CRTC2 and CRTC3 mRNA, as well as by Western blot with the respective CRTC antibodies.

\section{Chromatin immunoprecipitation}

To investigate whether CRTC3 binds directly to the Crf promoter, $\mathrm{Be}(2)$ M17 cells $\left(7 \times 10^{6}\right.$ cells) were cultured in $75 \mathrm{~cm}^{2}$ flasks (Sarstedt) in growth medium supplemented with $5 \mu \mathrm{M}$ retinoic acid for $3 \mathrm{~d}$ until $80 \%$ confluence $\left(\sim 20 \times 10^{6}\right.$ cells per flask). Cells were then stimulated with FSK and TGOT for $10 \mathrm{~min}$, as described above. Next, the stimulation medium was removed and replaced by $10 \mathrm{ml}$ of $1 \%$ formaldehyde fixation solution for $10 \mathrm{~min}$ at room temperature. Fixation was stopped by addition of glycine to a final concentration of $125 \mathrm{~mm}$ and incubation for $5 \mathrm{~min}$ at room temperature. Fixed cells were washed with ice-cold $1 \times$ PBS supplemented with $1 \mathrm{~mm}$ of the protease inhibitor phenylmethanesulfonylfluoride (PMSF), and harvested with $5 \mathrm{ml}$ of the same solution. The cell suspension was centrifuged for $8 \mathrm{~min}$ at $370 \times g$ and $4^{\circ} \mathrm{C}$, and the pellet was frozen at $-80^{\circ} \mathrm{C}$ until lysis in cell lysis buffer $(10 \mathrm{~mm}$ HEPES, $85 \mathrm{~mm} \mathrm{KCl}, 1 \mathrm{~mm}$ EDTA, 1\% NP-40). Frozen nuclear pellets were thawed, resuspended in $350 \mu$ l of nuclear lysis buffer $(50 \mathrm{~mm}$ Tris $/ \mathrm{HCl}$, $1 \%$ SDS, 0.5\% Empigen BB, 10 mm EDTA, 1 mm PMSF, $1 \times$ Protease Inhibitor (Roche) and sonicated five times for $10 \mathrm{~s}$ (30 s sample cooling between each sonification step) at output control 2 (Branson Sonifier 250 ) to produce $0.2-1 \mathrm{kbp}$ DNA fragments of chromatin. Five percent of the sonicated sample was separated and kept as input control. Immunoprecipitation was performed with either $4 \mu \mathrm{g}$ of CRTC3 antibody (Abcam, ab91654) or rabbit IgG as negative control at $4^{\circ} \mathrm{C}$ under rotation overnight. DNA-protein-antibody complexes were collected using protein A sepharose beads, washed, eluted, reverse cross-linked with proteinase K, and purified using Qiaquick PCR purification columns (Qiagen). Immunoprecipitated $C r f$ promoter was quantified using quantitative real-time PCR with primers designed to amplify the human Crf promoter region containing the CRE (forward: 5'-AGTCATAAGAAGCC CTTCCA-3'; reverse: 5' -CAACACTGAATCTCACATCCA-3'; Table 1). Fold-change in promoter occupancy is calculated as ( percentage input negative control signal $) /\left(\mathrm{TGOT}^{-} / \mathrm{FSK}^{+}\right)$group signal.

\section{Statistical analysis}

One-way (factor treatment) or two-way (factors treatment $\times$ time) ANOVA, followed by the Student Newmann-Keuls test, were performed for statistical analyses of behavioral and molecular experiments. Statistical significance was accepted at $p<0.05$. Data are presented as mean \pm or + SEM, as indicated in the figure legends. Statistical analyses were performed using SPSS (v19) for windows.

\section{Results}

\section{Intracerebroventricular infusion of TGOT induces MEK1/2} and CaMKII phosphorylation in the PVN

Infusion of TGOT $(1 \mathrm{nmol} / 2 \mu \mathrm{l})$ into the third ventricle doubled the phosphorylation of both CaMKII (1.9-fold change; $p=$ $0.047)$ and MEK1/2 (2.1-fold change; $p=0.001)$ within $10 \mathrm{~min}$ in the PVN (Fig. $2 A, B$ ), but not in the cortex, hippocampus, nor septum. In confirmation of previous results after intracerebroventricular OT or its antagonist in unstressed male and female rats under basal conditions (Neumann et al., 2000a; Slattery and Neumann, 2010) there were no effects of intracerebroventricular OT or TGOT on anxiety-like behavior in the LDB (data not shown). Thus, intracerebroventricular infusion of OT or TGOT either into the lateral or third ventricle activates the OTR and 
A
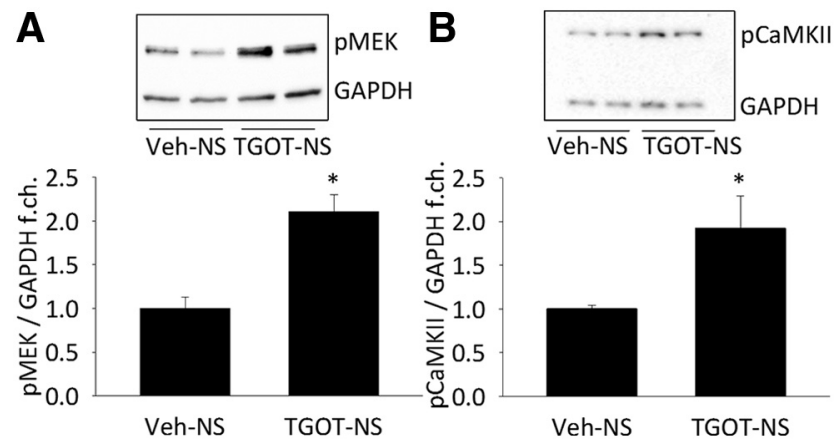

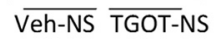

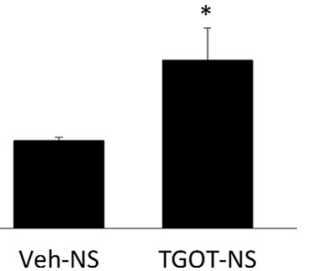

Figure 2. TGOT $(1 \mathrm{nmol} / 2 \mu \mathrm{l})$ infused into the third ventricle of nonstressed male rats (TGOT-NS) increases pMEK ( $\boldsymbol{A})$ and pCaMKII $(\boldsymbol{B})$ in the cytosolic fraction of PVN homogenates. Representative Western blots show the TGOT-induced increase of pMEK and pCaMKII relative to vehicle nonstressed (Veh-NS) controls in the PVN. This increase in pMEK or pCaMKII was absent in cytosolic fractions from hippocampus or septum homogenates. Phosphorylated protein was normalized to GAPDH. Data represent mean + SEM. ${ }^{*} p<0.05$ versus Veh-NS; $n=7-8$ in all groups. f.ch., Fold change.

downstream intracellular signaling pathways in the PVN, without influencing anxiety-related behavior.

\section{OT delays stress-induced $\mathrm{Crf}$ gene transcription and plasma ACTH increase}

Vehicle-treated/restraint stressed (VEH-RS) rats displayed a rapid increase in Crf hnRNA in the PVN with maximal levels observed between 10 and $15 \mathrm{~min}$ of restraint, and returning to near-basal levels by $30 \mathrm{~min}$ (Fig. $3 \mathrm{~A}$ ). OT delayed this stressinduced response (OT-RS group), with peak Crf hnRNA values found at $15 \mathrm{~min}$ and a slower decrease to basal levels (two-way ANOVA; factors treatment $\times$ time $F_{(3,48)}=195.4$; $p=0.001$; Fig. $3 A$ ). After $10 \mathrm{~min}$ of stress, OT-RS rats showed a reduced $C r f$ hnRNA level compared with VEH-RS controls $(p=0.001)$, whereas at the $30 \mathrm{~min}$ time point, $C r f$ hnRNA levels of OT-RS rats were higher than both basal levels and those of VEH-RS animals ( $p=0.001$; Fig. $3 A$ ). There was no difference in $C r f$ hnRNA expression within the PVN between OT-NS and VEH-NS rats, indicating that OT has no effect on Crf expression under basal, nonstressed conditions.

As expected, no significant changes in Crf mRNA levels were measured within the time points examined (up to $30 \mathrm{~min}$ ) in any of the groups (Fig. 3B), consistent with the observation that changes in $C r f$ mRNA levels require at least $1 \mathrm{~h}$ to occur (Ma et al., 1997).

We found minor, yet statistically significant, effects of OT treatment on the plasma ACTH response to restraint stress (treatment $\times$ time $F_{(3,36)}=3.4 ; p=0.032$, Fig. $\left.3 C\right)$. In the VEH-RS group, plasma ACTH concentrations peaked at $10 \mathrm{~min}$ and remained elevated until the end of the stressor. In the OT-RS rats, plasma ACTH tended to be lower at $10 \mathrm{~min}$ ( $p=0.065$ vs VEH$\mathrm{RS}$ ), and showed a delayed peak $15 \mathrm{~min}$ after RS ( $p=0.039$ vs OT-RS at $10 \mathrm{~min})$, thus, being significantly higher $(p=0.035)$ than those in VEH-RS animals at $15 \mathrm{~min}$. At $30 \mathrm{~min}$, ACTH levels of Veh-RS and OT-RS-treated rats did not differ (Fig. 3C; $p=$ 0.109 ). Thus, OT infused intracerebroventricularly before the onset of restraint stress delays the increase of Crf gene transcription following restraint stress, with minor effects on ACTH plasma levels.

\section{OT reduces CRTC3 activation/translocation in the PVN during short exposure $(10 \mathrm{~min})$ to restraint stress}

To study the mechanism underlying the effects of OT on Crfgene expression in vivo, we examined the translocation of CRTC fol-

lowing 10 min of restraint stress. In VEH-RS rats, stress exposure decreased cytosolic levels of CRTC2 (not significant) and CRTC3 $(p=0.007)$ compared with VEH-NS rats (Fig. $4 A, C)$. This reduction was reflected in the nuclear compartment, where CRTC2 and CRTC3 levels were both significantly increased ( $p=0.03$ for both; Fig. $4 B, D ; n=7)$.

Treatment of rats with TGOT before restraint (TGOT-RS) prevented the nuclear translocation of CRTC2 and CRTC3, with CRTC levels in both compartments not being significantly different from those in the Veh-RS control-group (Figs. 4A-D). TGOT infusion in nonstressed animals had no effect either on CRTC2 and CRTC3 levels in the cytosol, or in the nucleus. These data suggest that TGOT inhibits the stress-induced activation, and subsequent translocation, predominantly of CRTC3 and to a lesser extent of CRTC2. Neither restraint stress nor intracerebroventricular TGOT infusion affected CRTC translocation in the cortex, demonstrating the specificity of the effects of stress and TGOT (data not shown; for region-specific CRTC expression levels, see Watts et al., 2011).

As CRTCs are cofactors of CREB signaling, we assessed whether TGOT inhibits the stress-induced CREB phosphorylation. Intracerebroventricular infusion of TGOT did not influence the increase of pCREB following $10 \mathrm{~min}$ of restraint stress, suggesting that OT regulates $\mathrm{Crf}$ gene expression through modulation of CRTC translocation, rather than CREB phosphorylation $(n=5$; Fig. $4 E, F)$.

Together, our in vivo results suggest that OT delays the peak of Crf transcription activity, and that this effect is mediated by the attenuation of CRTC nuclear translocation.

\section{Colocalization of $\mathrm{Cr} f$ and OTR in mice}

To determine whether the effects of TGOT on Crf expression are mediated by OTR expressed in Crf-positive cells, we used OTRVenus reporter mice (Yoshida et al., 2009). However, the number of GFP/OTR-positive cells, was extremely low in the PVN (as previously reported by Yoshida et al., 2009), making it impossible to study colocalization of $\mathrm{Crf}$ and OTR. Nevertheless, in stressed mice there was a substantial augmentation of $C r f$-expressing cells (Fig. $5 A, B$ ), and CRTC3 translocation to the nucleus (Fig. $5 J$ ). In contrast, the number of GFP/OTR-positive cells was not increased by the $30 \mathrm{~min}$ stress protocol. The number of cells expressing GFP/OTR in the adult amygdala, on the other hand, was high, but these cells did not express $\operatorname{Crf}$ (Fig. 5D-F), as previously reported (Gray and Magnuson, 1992; Gray, 1993; Haubensak et al., 2010). We conducted further studies using hypothalamic primary neuron cultures and cell lines shown to coexpress the OTR and Crf to determine whether the observed OT effect on stressinduced Crf expression in vivo is, at least partly, due to direct actions on Crf-positive cells.

Interestingly, a high degree of colocalized Crf and OTR was observed in the amygdala of embryonic OTR-reporter mice, in contrast to adult mice, suggesting developmental changes in the localization and coexpression of Crf and OTR-expressing cells within the amygdala (Fig. 5G-I). Thus, we also included an embryonic amygdala cell line in our investigations.

\section{OT reduces FSK-induced $C r f$ hnRNA and delays CRTC3} translocation in rat hypothalamic and amygdala cells Stimulation of rat embryonic (E18) primary hypothalamic neurons with FSK $(1 \mu \mathrm{M})$ and/or TGOT $(10 \mathrm{nM})$ revealed a striking similarity in the pattern of CrfhnRNA expression compared with our in vivo findings from adult rat hypothalamic PVN tissue. FSK induced a rapid increase of Crf hnRNA levels, which peaked at 

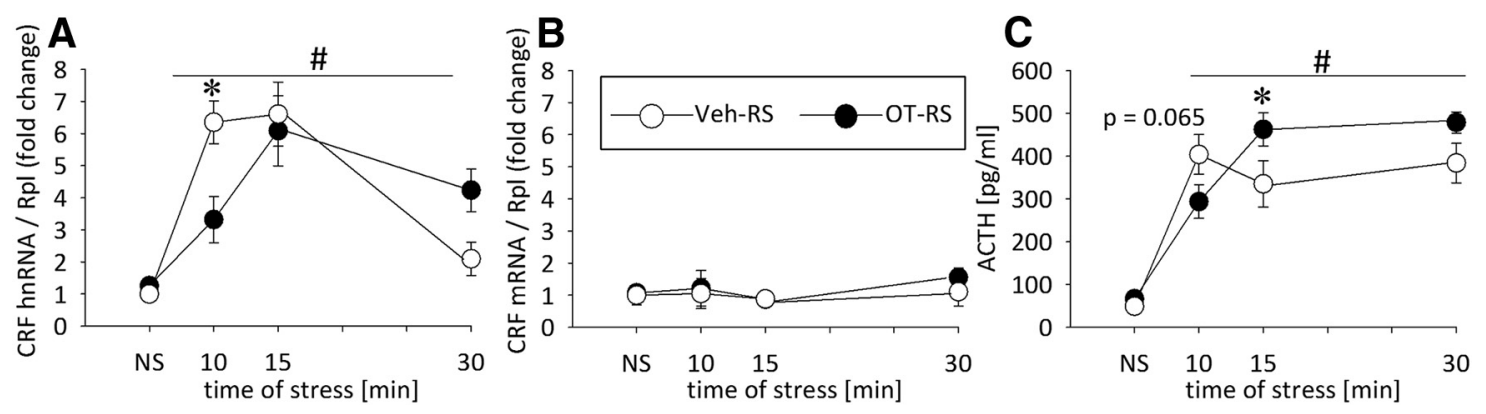

Figure 3. OT ( $1 \mathrm{nmol} / 2 \mu$ linfused into the third ventricle) delays RS-induced (rfgene transcription in the PVN $(\boldsymbol{A})$ and plasma ACTH response $(\boldsymbol{C})$. $\boldsymbol{A}$, The stress-induced increase in $(r f$ hnRNA levels (Veh-RS) is delayed by an 0T infusion 10 min earlier (OT-RS), as is the subsequent return to basal levels. $\boldsymbol{B}$, Neither stress nor $0 \mathrm{~T}$ affects (rf mRNA levels within the observed 30 min period. $C, 0 \mathrm{~T}$ tends to delay the increase in plasma ACTH levels induced by restraint stress, and increases slightly, but significantly, stress-induced ACTH peak levels. Under stress-free conditions, intracerebroventricular $0 \mathrm{~T}$ is without effect in all of the experiments (OT-NS). Data represent mean $\pm \mathrm{SEM}{ }^{*} p<0.05$ versus Veh-RS group at the respective time point; $\# p<0.05$ versus respective NS group; $n=4$ (10 and $15 \mathrm{~min})$, or $n=8$ (NS, $30 \mathrm{~min}$ ) for all figures.
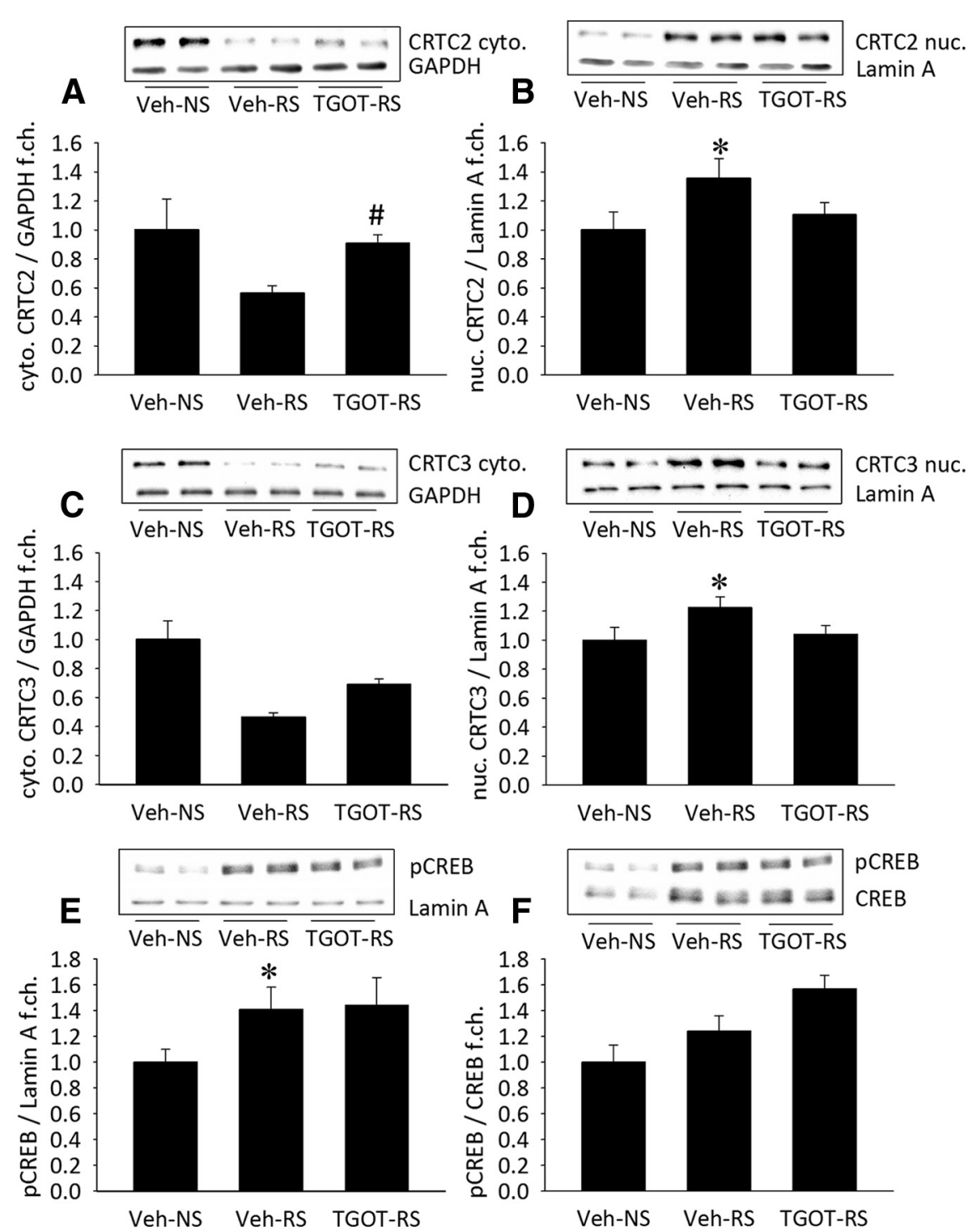

Figure 4. TGOT prevents the RS-induced translocation of CRTC2 and CRTC3 from the cytosol to the nucleus without modifying stress-induced pCREB in PVN protein extracts. TGOT ( $1 \mathrm{nmol} / 2 \mu \mathrm{l}$, third ventricle, infused 10 min before stress onset) prevents the RS-induced decrease in cytosolic CRTC2 (A), the simultaneous increase in nuclear CRTC2 (B), the decrease in cytosolic CRTC3 levels observed after RS ( $(\boldsymbol{C})$, and the simultaneous increase in nuclear CRTC3 levels (D). CRTC2/3 levels were normalized for total protein levels to $\operatorname{GAPDH}(\boldsymbol{A}, \boldsymbol{C})$, or lamin $A(\boldsymbol{B}, \boldsymbol{D})$. The RS-induced increase in nuclear pCREB is not influenced by TGOT when normalized for total protein $(\boldsymbol{E})$ or total CREB $(\boldsymbol{F})$ levels. Representative Western blots are provided for each dataset. Data representmean + SEM. $n=5-7$ in all groups. ${ }^{*} p<$ 0.05 versus VEH-NS; \#p $<0.05$ versus VEH-RS. f.ch., Fold change; cyto., cytosolic; nuc, nuclear.
20-30 $\min (p<0.001$ for both time points), and returned to near-basal levels $(p=0.061)$ at $90 \mathrm{~min}$. The peak levels at 20-30 min in the $\mathrm{TGOT}^{-} / \mathrm{FSK}^{+}$group were lowered by the presence of TGOT in the incubation medium $\left(\mathrm{TGOT}^{+} / \mathrm{FSK}^{+}\right.$ group), being significantly reduced to $74 \pm 4.6 \%$ at $30 \mathrm{~min}(p=0.002)$. Also, TGOT prolonged the duration of FSKinduced Crf gene expression, as Crf hnRNA levels were still elevated at the 90 min time point (Fig. $6 A$; treatment $\times$ time; $\left.F_{(5,84)}=4.6 ; p<0.001\right)$.

The protein yield of the primary cultures was too low to separate cytosolic and nuclear fractions to analyze CRTC2 and CRTC3 translocation and CREB phosphorylation by Western blotting. Therefore, we made use of the immortalized rat hypothalamic cell line H32 (Mugele et al., 1993), because of its hypothalamic origin and expression of endogenous OTR (Blume et al., 2008). Although these cells have lost Crf gene expression, the CREBCRTC signaling pathway that is known to regulate Crf gene expression (Liu et al., 2011), and intracellular pathways that are coupled to the OTR, are still intact (Blume et al., 2008). In H32 cells, we found no effect of TGOT on the FSK-induced, transient CREB phosphorylation, peaking at $10 \mathrm{~min}$ and returning to baseline $20 \mathrm{~min}$ after the incubation started (Fig. 6B). Likewise, the FSK-induced increase of nuclear CRTC2 levels was not affected by TGOT during the first $60 \mathrm{~min}$ after administration (Fig. 6C), but a further increase in nuclear CRTC2 was found 90 min after the application of both compounds $(p=0.047)$.

In sharp contrast, TGOT had profound effects on the FSK-stimulated increase in nuclear CRTC3 levels of H32 cells (Fig. 6D). FSK alone augmented CRTC3 in the nucleus with a peak at 10 min after the onset of FSK stimulation 
$(p<0.001)$, and maintained elevated nuclear CRTC3 levels during the $90 \mathrm{~min}$ of incubation $(p<0.001)$. Treatment of $\mathrm{H} 32$ cells with TGOT in FSK ${ }^{+}$cells reduced the fast peak that was seen in TGOT $^{-} / \mathrm{FSK}^{+}$cells at $10 \mathrm{~min}(p=$ 0.007). Nuclear CRTC3 levels steadily increased until their maximum was reached at 60 min to a level that was $\sim 1$.4-fold higher than the peak levels induced in TGOT $^{-} / \mathrm{FSK}^{+}$-treated cells (treatment $\times$ time, $\left.F_{(6,64)}=5.3 ; p<0.001\right)$. After 60 min, a rapid drop in nuclear CRTC3 levels in $\mathrm{TGOT}^{+} / \mathrm{FSK}^{+}$-treated cells annulled the differences between $\mathrm{TGOT}^{+} / \mathrm{FSK}^{+}$ and TGOT $^{-} / \mathrm{FSK}^{+}$cells. Similar effects of TGOT on CRTC3 translocation were observed in the amygdala cell line Ar-5. As experimental evaluation of the optimal dose of FSK in $\mathrm{Be}(2) \mathrm{M} 17$ cells revealed maximal CRTC3 translocation and CRF transcription at $50 \mu \mathrm{M}$ FSK (see below; Mulchahey et al., 1999) we chose this concentration also for Ar- 5 cells. FSK induced a peak level of nuclear CRTC3 at $30 \mathrm{~min}$, which declined to almost basal levels at 90 min. OT reduced this FSK-induced peak of nuclear CRTC3 significantly ( $p=$ 0.009 ) at $30 \mathrm{~min}$ by $\sim 30 \%$ (Fig. $6 E$; treatment $\times$ time, $\left.F_{(12,99)}=3.893 ; p<0.001\right)$. In all of the experiments, in primary, $\mathrm{H} 32$, and Ar-5 cells cells, $\mathrm{TGOT}^{+} / \mathrm{FSK}^{-}$was without effect (Fig. 6).

The data from the restraint stress experiments, together with those obtained in cell culture, suggest that OT controls Crf expression through inhibition of nuclear translocation of CRTC3 during stress at early time points, but not under basal (NS or $\mathrm{FSK}^{-}$) conditions.

\section{OT inhibits $C r f$ gene transcription in the human adult cell line $\mathrm{Be}(2)-\mathrm{M} 17$ via CRTC3}

To test the hypothesis that OT exerts its effects on Crf gene transcription via CRTC3, it is necessary to assess $\operatorname{Crf~hn-~}$ RNA and nuclear CRTC levels in the same cell type. Therefore, we used the human adult neuroblastoma cell line $\mathrm{Be}(2)-\mathrm{M} 17$, which differentiates into neurons following exposure to retinoic acid. These cells express Crf and the OTR, as well as the CREBCRTC signaling pathway, which allowed us to determine effects of TGOT on CRTC translocation, CREB phosphorylation, and Crf gene expression in one system. In initial experiments, lower concentrations (1-10 $\mu \mathrm{M}$ ) of FSK, as used for the H32 cells, failed to induce reproducible increases in Crf hnRNA, whereas a $50 \mu \mathrm{M}$ concentration resulted in a reproducible and constant increase in Crf transcript (for comparable concentrations, see Sala et al., 2000; Heo et al., 2013). Therefore, this concentration was chosen for the rest of the $\mathrm{Be}(2)-\mathrm{M} 17$ and Ar-5 experiments. Application of TGOT at a concentration of 10 and $100 \mathrm{~nm}$ were equally effec-

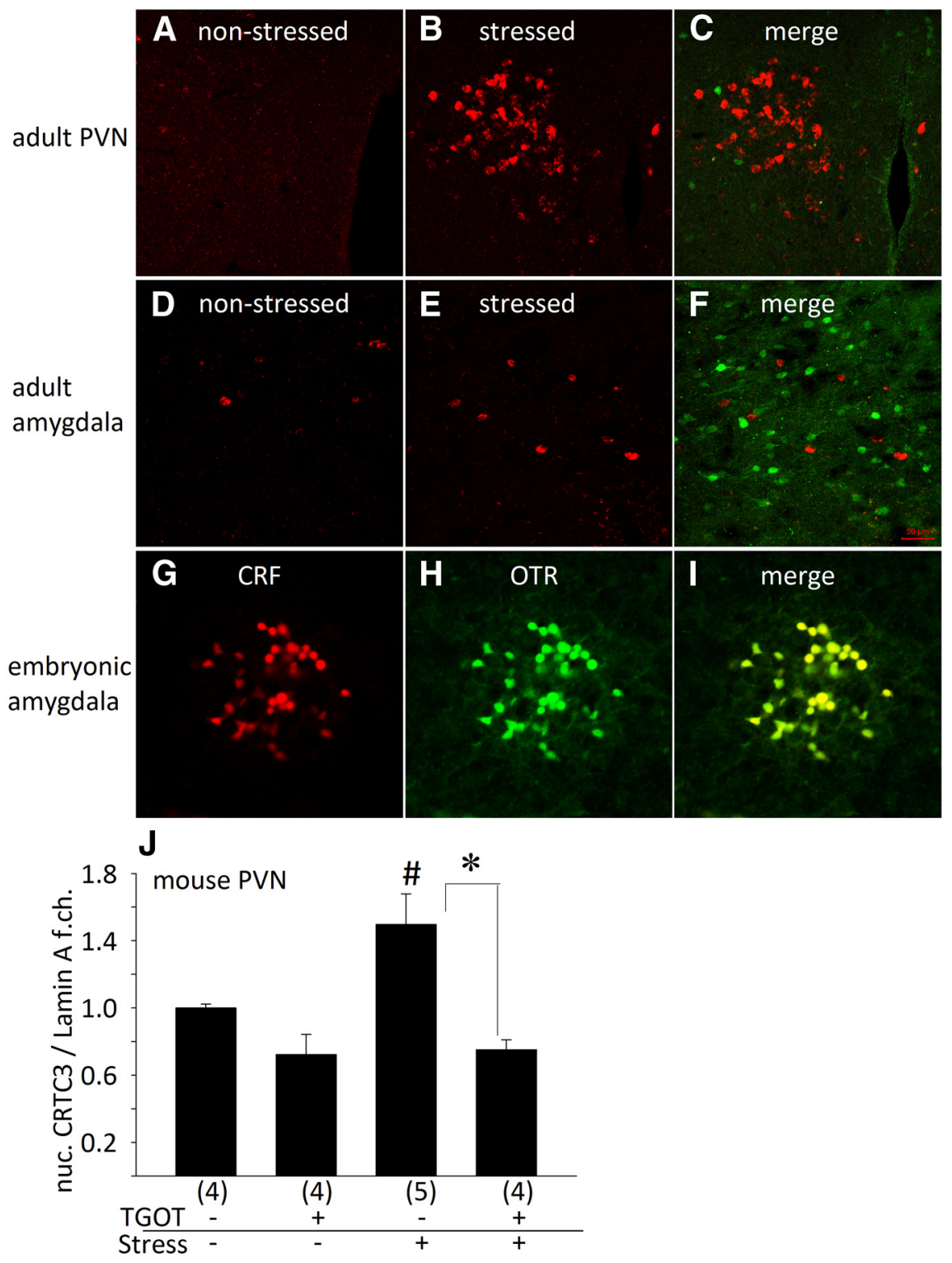

Figure 5. Expression of the OTR and (rf in the PVN and amygdala. Fluorescent in situ hybridization of $(r f m R N A$ (red) in the PVN of NS $(\boldsymbol{A})$ and $30 \mathrm{~min}$ RS $(\boldsymbol{B})$ mice, with tissue taken 90 min after stress termination. $\boldsymbol{C}$, OTR-Venus reporter GFP signal (green) merged with red $(r f$ channel signal from $\boldsymbol{B}$. Absence of staining indicates a detection limit that is below the 0TR expression level in Crf channel from $E$ reveals no colocalization of $(r f$ and $0 T R$ in the adult stressed mouse amygdala. E18.5 amygdala Crf staining and OTR expression $(\boldsymbol{G}, \boldsymbol{H})$ reveal almost complete coexpression $(\boldsymbol{I})$. J, Mouse PVN tissue reveals increased CRTC3 translocation upon 10 min of restraint stress and a reduction of this stress-induced increase by intracerebroventricular infusion of TGOT $10 \mathrm{~min}$ before the onset of the stressor. Scale bar, $50 \mu \mathrm{m} . n=6-7$, Data represent mean \pm SEM, $\# p<0.05$ versus TGOT ${ }^{-} / \mathrm{RS}^{-}{ }^{-} ;{ }^{*} p<0.05$ versus $\mathrm{TGOT}^{+} / \mathrm{RS}^{+}$. f.ch., Fold change; nuc., nuclear.

tive in inhibiting the FSK-induced increase of Crf expression, so we used $10 \mathrm{~nm}$ throughout the rest of the experiments.

A temporal analysis showed that stimulation of $\mathrm{Be}(2)-\mathrm{M} 17$ cells with $50 \mu \mathrm{M}$ of FSK augmented Crf hnRNA levels, which reached their maximum after $60 \mathrm{~min}$ and remained elevated until at least $90 \mathrm{~min}$. TGOT affected FSK-induced Crf hnRNA (treatment $\times$ time $\left.F_{(3,41)}=4.4 ; p=0.01\right)$, with lower levels observed at $60 \min (p<0.001)$ and $90 \min (p=0.005)$ after the onset of the incubation compared with vehicle/FSK. Incubation with TGOT alone was without effect on Crf hnRNA levels at any of the time points measured (Fig. 7A). The effects of TGOT on FSK-induced Crf transcription were blocked by a specific OTR antagonist 

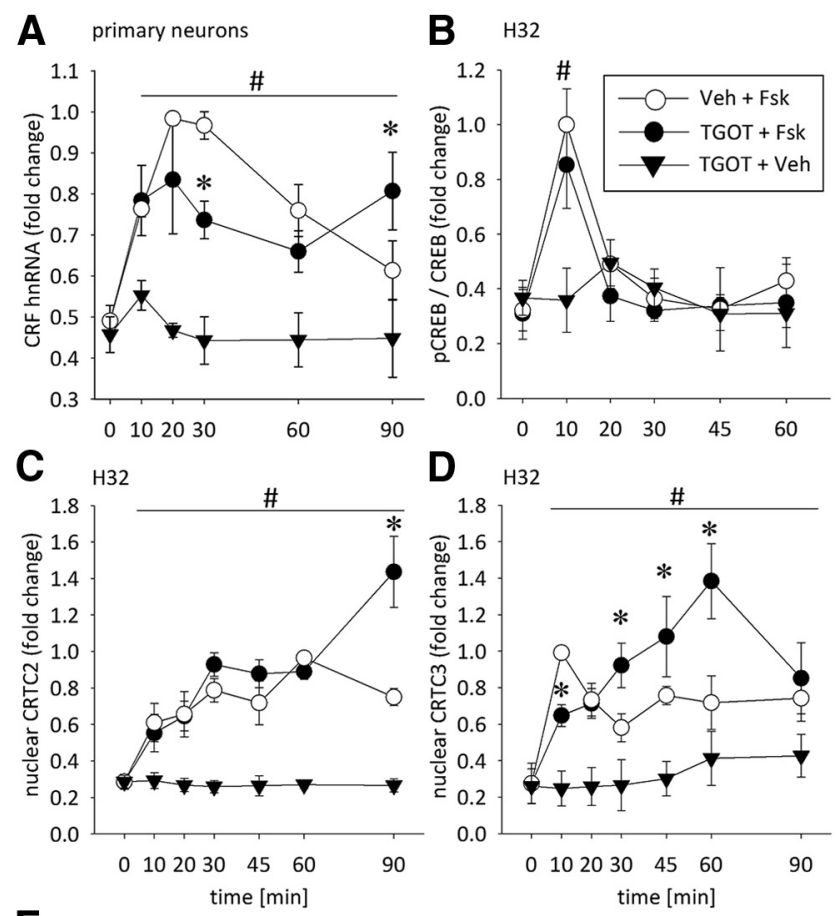

E

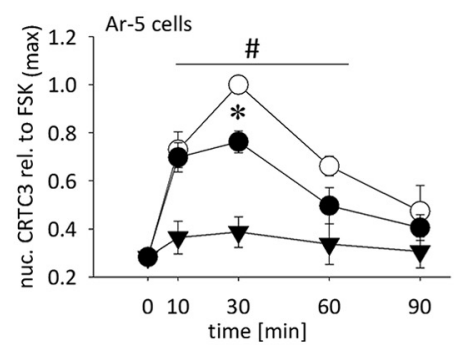

Figure 6. TGOT (10 nm) reduces the FSK $(1 \mu \mathrm{m})$-induced increase of $(r f$ hnRNA levels in primary cells, and delays the FSK-induced increase of nuclear CRTC3 levels in rat hypothalamic cells. $A$, In primary hypothalamic cells, the Crf hnRNA levels that are augmented by FSK, peak between 20 and 30 min of incubation; peak levels were set to 1 to make comparisons across multiple independent experiments possible in this and subsequent figures. TGOT reduces the magnitude of the CrfhnRNA response, and delays the return to basal levels; $n=7 . B$, TGOT does not affect the FSK-induced increase of CREB phosphorylation. Normalization was relative to total CREB band intensity; $n=5$. C, TGOT has no effect on the FSK-induced increase of normalized (to lamin A) nuclear CRTC2 levels until 60 min of incubation; $n=8$. D. TGOT delays the FSK-induced normalized nuclear CRTC3 levels, but increases these to 1.4-fold higher at $60 \mathrm{~min}$ compared with the maximum response to $\mathrm{FSK}$ alone at $10 \mathrm{~min} ; n=8$. $E$, The amygdala cell line Ar-5 shows a significant reduction of FSK ( $50 \mu \mathrm{m})$-induced CRTC 3 translocation when costimulated with TGOT (10 nM) $30 \mathrm{~min}$ after the onset of stimulation; $n=5$. Data represent mean \pm SEM. ${ }^{*} p<0.05$ versus TGOT-/FSK ${ }^{+} ; \# p<0.05$ versus respective 0 min time point $\left(\right.$ TGOT $^{-}$/ $\mathrm{FSK}^{+}, \mathrm{TGOT}^{+} / \mathrm{FSK}^{+}$groups). f.ch., Fold change; nuc., nuclear.

(OTA, $1 \mu \mathrm{M} ; p<0.001$ vs $\mathrm{OTA}^{-} / \mathrm{TGOT}^{+} / \mathrm{FSK}^{+}$; Fig. $7 B$ ), demonstrating the involvement of OTRs, rather than vasopressin receptors. OTA without FSK or TGOT had no effect on Crf hnRNA levels. Furthermore, the delayed increase of FSK-induced Crf hnRNA levels in the presence of TGOT translated into reduced mRNA synthesis at $90 \mathrm{~min}(p=0.008)$, but increased mRNA levels at time points from $180 \mathrm{~min}$ on $(p<0.001$; Fig. $7 C)$. Finally, CRTC translocation correlated with the observed effects on Crftranscription. FSK induced a short-lived increase of nuclear CRTC2 levels ( $p=0.005)$, peaking after $10 \mathrm{~min}$ of incubation and returning to basal levels shortly thereafter (Fig. 7D), which is in contrast to $\mathrm{H} 32$ cells, where the response lasts for up to at least $90 \mathrm{~min}$. In the presence of TGOT, FSK $\left(\mathrm{TGOT}^{+} / \mathrm{FSK}^{+}\right)$ failed to augment nuclear CRTC2, however, no significant difference between the $\mathrm{TGOT}^{-} / \mathrm{FSK}^{+}$and the $\mathrm{TGOT}^{+} / \mathrm{FSK}^{+}$group was found (treatment $\times$ time, $F_{(3,31)}=0.47 ; p=0.707$ ).

As observed with CRTC2, FSK induced a peak level of CRTC3 at 10 min of treatment with elevated, submaximal levels at 30 and 60 min of treatment (treatment $\times$ time; $F_{(4,52)}=2,56 ; p=0.05$ ). In contrast, in the $\mathrm{TGOT}^{+} / \mathrm{FSK}^{+}$group this peak of nuclear CRTC3 at 10 min was absent $(p=0.016)$, however, levels steadily increased until at least $60 \mathrm{~min}$ of treatment, being no longer different from the $\mathrm{TGOT}^{-} / \mathrm{FSK}^{+}$group at the 30 and $60 \mathrm{~min}$ time points (Fig. 7E).

The FSK-induced phosphorylation of CREB was not affected by TGOT (Fig. $7 G$ ), again suggesting that OT does not control Crf expression by modulation of CREB phosphorylation.

Thus, the effects of TGOT on FSK-induced changes in Crf gene expression seen in the human neuroblastoma cell line Be(2)-M17 as measured by hnRNA levels, mRNA levels, CRTC2 and CRTC3 translocation, and CREB phosphorylation are strikingly similar to those observed in the rat hypothalamic and amygdala cells, both in vivo and in vitro, as well as in the mouse PVN in vivo. Therefore, we concluded that the Be(2)-M17 cells are a suitable model to further study the modulatory role of OT on CRTC translocation and the control of Crf gene expression.

\section{CRTC3 is necessary for the inhibition of $\mathrm{Crf}$ gene expression by OT}

To determine whether CRTC2 and/or CRTC3 are necessary for the inhibition of $\mathrm{Crf}$ gene expression by OT, we downregulated the expression of CRTC2 and CRTC3 by transfecting the Be(2)M17 cells with siRNA oligonucleotides. The CRTC2 siRNA construct downregulated both CRTC2 and CRTC3 mRNA levels by $60 \%(p=0.002)$ and $20 \%(p=0.019)$, respectively $\left(F_{(3,15)}=\right.$ 20.45; $p<0.001$; Table 3). The CRTC2 mRNA downregulation was mirrored at the protein level (64\%), whereas CRTC3 protein levels did not change. The CRTC3 siRNA construct specifically reduced both CRTC3 mRNA $\left(F_{(3,15)}=3.54 ; p=0.048\right)$ and protein levels by $60 \%(p=0.017)$. The nonspecific control siRNA oligonucleotide was without effect (Table 3 ).

To assess whether the inhibitory effect of TGOT on FSKinduced Crf transcription depends on CRTC2 or CRTC3, we stimulated the cells for 60 min with FSK, when Crf hnRNA levels were maximal (Fig. 8A). Statistical analysis revealed a significant effect of $\mathrm{TGOT}^{+} / \mathrm{FSK}^{+}$treatment $\left(F_{(3,27)}=33.93 ; p<0.001\right.$; Fig. $8 A)$, and of pretreatment with siRNA constructs $\left(F_{(3,27)}=\right.$ $17.4 ; p<0.001)$. Student-Newman-Keuls post hoc analyses confirmed the significant reduction in $\mathrm{FSK}^{+}$-stimulated $\mathrm{Cr} f \mathrm{hnRNA}$ levels by TGOT in the three groups pretreated with either vehicle $(p<0.001)$, control oligo $(p=0.018)$, or siCRTC2 $(p=0.005)$. Cells that were pretreated with the CRTC3 siRNA construct revealed a less pronounced FSK-induced rise in Crf hnRNA (50\% of vehicle or control oligo pretreated cells, $p<0.001$ ). Importantly, TGOT treatment was without effect on Crf transcript levels in CRTC3 siRNA transfected cells. We exclude a floor effect, as levels of both, $\mathrm{TGOT}^{-} / \mathrm{FSK}^{+}$and $\mathrm{TGOT}^{+} / \mathrm{FSK}^{+}$, remained three times higher than $\mathrm{TGOT}^{-} / \mathrm{FSK}^{-}$controls (this group was set to 1 ; Fig. $8 A$, dashed line). This indicates that the effect of TGOT on FSK-induced Crf gene expression depends exclusively on CRTC3. The lack of effect of pretreatment with the CRTC2 siRNA construct might be explained by the observation that nuclear CRTC2 levels have already returned to basal levels after 60 min of FSK incubation (Fig. 7C).

To demonstrate the unique role of CRTC3 in the reduction of FSK-induced Crf expression by TGOT further, we studied the 
binding of CRTC2 and CRTC3 to the Crf promoter after 10 min of FSK incubation. At this time point, the FSK-induced increase of both CRTC2 and CRTC3 nuclear levels are maximal (Figs. $7 C, D$ ). The chromatin immunoprecipitation analyses showed that binding of CRTC2 and CRTC3 to the Crf promoter was induced by FSK (Fig. $8 B, C$; one-way ANOVA, $F_{(3,15)}=$ $10.7 ; p=0.001$ for CRTC2; $F_{(3,19)}=4.4 ; p=$ 0.02 for CRTC3), and that TGOT prevented CRTC3 ( $p=0.028$ ), but not CRTC2 binding to the Crf promoter. Again, $\mathrm{TGOT}^{+} /$ $\mathrm{FSK}^{-}$was without effect. This supports the hypothesis that OT mediates the downregulation of $\mathrm{Crf}$ transcription during stress via CRTC3, but not CRTC2.

\section{Discussion}

The current study describes a novel molecular mechanism recruited by OT to regulate $\mathrm{Crf}$ expression during acute stress exposure. Central to this mechanism is the inhibition, or delay, of CRTC3 translocation from the cytosol to the nucleus, resulting in reduced CRTC3 binding to the $C r f$ promoter and $C r f$ gene expression. The control of Crf expression is a completely novel role of CRTC 3 in the brain, which is only active during stress, not under basal (stress-free) conditions. The present data show that it operates within the PVN of both rats and mice in vivo, and in cells of human and rat (Wistar and Sprague-Dawley strains) origin, suggesting that this mechanism is conserved across mammalian species. Furthermore, our in vitro data show that prolonged exposure to FSK and TGOT leads to a potentiation of $\mathrm{Crf}$ expression. Thus, the early inhibition and the late potentiation of $\mathrm{Crf}$ expression by CRTC3 translocation and promoter binding might explain the contradictory results of previous studies describing either inhibitory (Windle et al., 2004) or potentiating effects (Petersson et al., 1999) of OT on ACTH release.

The present in vitro experiments clearly show that OT can directly regulate $\mathrm{Crf}$ transcription in Crf-expressing neurons. Importantly, the kinetics of the cellular responses in vitro parallel those we observed in vivo, which is consistent with a direct effect of OT on Crf-expressing cells. However, the inability to demonstrate colocalization of the OTR and Crfin the PVN raises questions as to whether the in vitro findings do indeed apply to the mechanism by which OTR activation, and subsequent CRTC3 translocation, reduce Crf expression in vivo. Lack of visualization of the OTR within the PVN is likely to be the consequence of low expression lev-
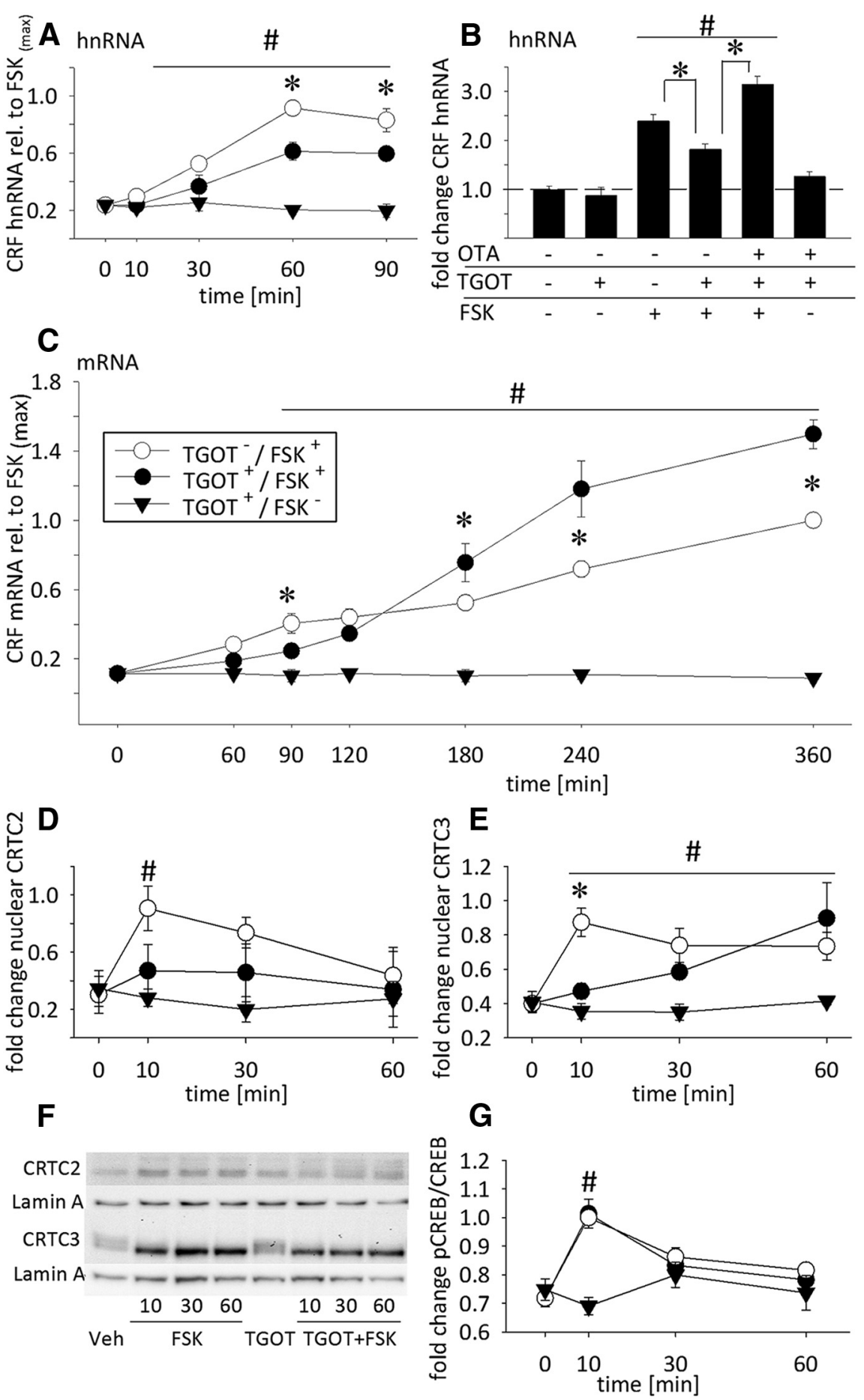

Figure 7. TGOT alters FSK-induced CrfhnRNA, mRNA, and CRTC2/3 translocation in Be(2)-M17 cells. $\boldsymbol{A}$, Incubation with FSK (50 $\mu \mathrm{m}$ ) augmented ( $r f$ hnRNA levels from 20 min onward, reaching maximal levels at 60 min. TGOT attenuated the FSK-induced increase at 60 and $90 \mathrm{~min}$, but was without effect in the absence of FSK; $n=7$. B, Sixty minutes of FSK stimulation induced a 2.4-fold increase of $C r f h n R N A$ levels, which was reduced to 1.8-fold by TGOT. In the presence of an OTA, TGOT no longer affected the FSK induced increase in C $r$ hnRNA levels. The inhibitor alone had no effect; $n=10$ except OTA ${ }^{-} / \mathrm{TGOT}^{+} / \mathrm{FSK}^{-} ; n=5$. C, Crf mRNA levels increase from 90 min until at least 360 min after the onset of stimulation. TGOT reduced this increase at 90 min, but stimulated higher levels of C $r$ mRNA compared with FSK-induced levels from 180 min until $360 \mathrm{~min} ; n=6$. D, FSK increased nuclear CRTC2 levels at 10 min after the onset of incubation, which then returned to basal as off $30 \mathrm{~min}$. TGOT prevented the FSK-induced increase of nuclear CRTC2. TGOT alone was without effect; $n=5$. E, FSK-induced nuclear CRTC3 levels reached their maximum at $10 \mathrm{~min}$, and remained elevated for at least $60 \mathrm{~min}$. TGOT delayed this response. TGOT without FSK had no effect on nuclear CRTC3 levels; $n=5-8$. F, Representative Western blots showing CRTC2, CRTC3, and respective lamin A loading controls. G, pCREB levels transiently increased at 10 min in FSK-stimulated cells and this was not modulated by TGOT. pCREB levels were normalized to total CREB and lamin $A$, and gave identical results. Therefore, only the $p C R E B / C R E B$ normalization is shown; $n=5$. Data represent mean $\pm S E M$. Data are relative to maximum response to FSK incubation to make comparisons across experiments possible. ${ }^{*} p<0.05$ versus TGOT ${ }^{-} /$FSK $^{+}$group; $\# p<0.05$ versus respective 0 min time point. rel., Relative. 
Table 3. Target specificity of the CRTC2 and CRTC3 siRNA constructs

\begin{tabular}{|c|c|c|c|c|c|c|}
\hline & \multicolumn{2}{|c|}{ mRNA } & \multicolumn{2}{|c|}{ protein } & \multirow{2}{*}{\multicolumn{2}{|c|}{ We $=$ CRTC2 }} \\
\hline & CRTC2 & CRTC3 & CRTC2 & CRTC3 & & \\
\hline & $\begin{array}{c}\% \text { change } \\
\text { (SEM) }\end{array}$ & $\begin{array}{c}\% \text { change } \\
\text { (SEM) }\end{array}$ & $\begin{array}{c}\% \text { change } \\
\text { (SEM) }\end{array}$ & $\begin{array}{l}\% \text { change } \\
\text { (SEM) }\end{array}$ & tan bes net & CRTC3 \\
\hline CRTC2 siRNA & $-59(5.3)$ & $-22(20.5)$ & $-64.6(5.5)$ & $+7.1(15.7)$ & & \\
\hline CRTC3 siRNA & $-19.5(3.6)$ & $-61.8(0.8)$ & $-8.4(0.6)$ & $-67.6(0.6)$ & & \\
\hline
\end{tabular}

CRTC2 and CRTC3 siRNAs effectively downregulate their respective target mRNA and protein. A minor nonspecific effect of CRTC2 siRNA on CRTC3 mRNA, but not protein, was observed. Data are expressed as percent change relative to untreated Be(2)-M17 cells. Representative Western blot showing protein levels of normalized (to Lamin A) CRTC2 and CRTC3 after siRNA treatment. $n=3$.
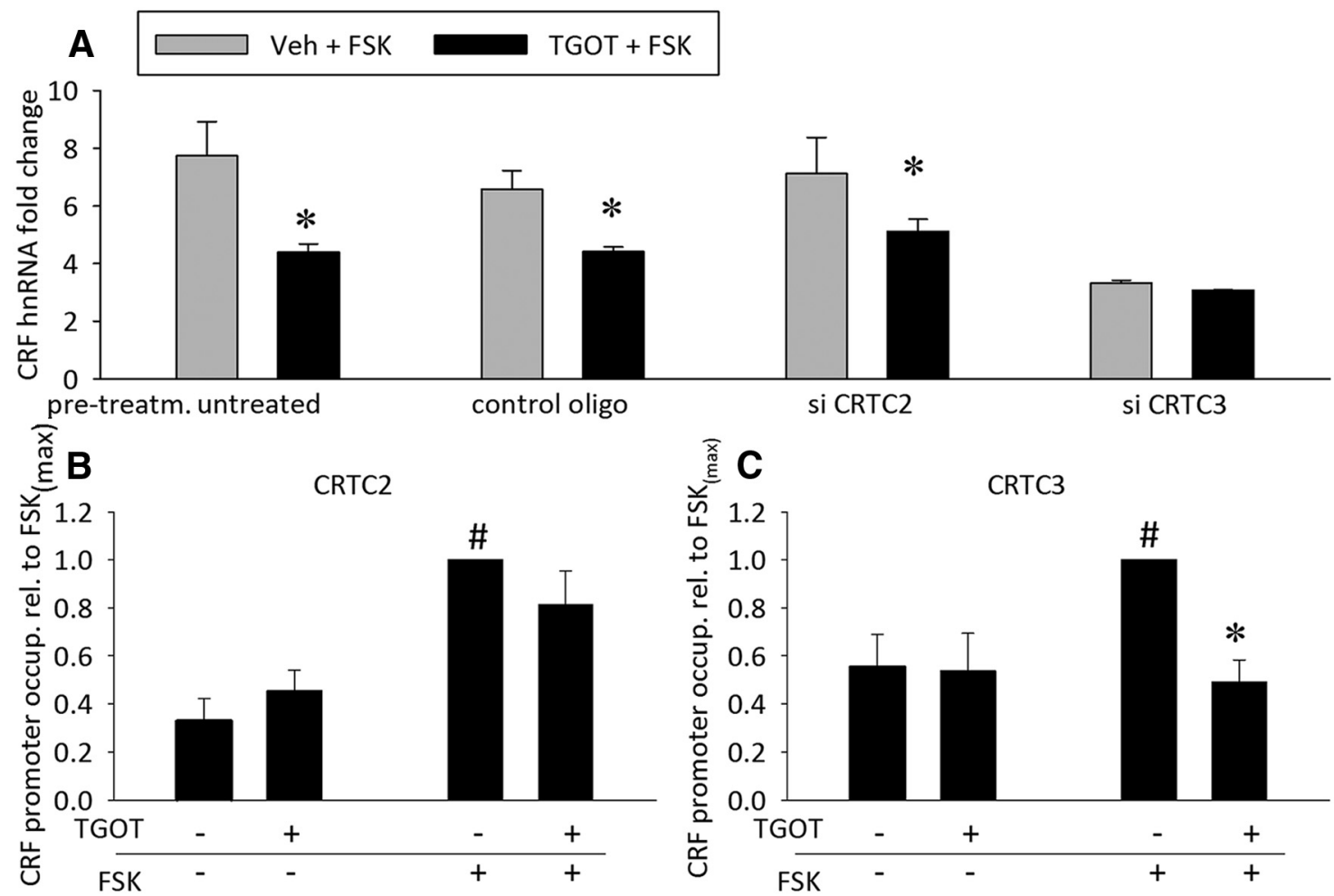

Figure 8. CRTC3 mediates the inhibitory effects of OT on FSK-induced Crftranscription. $A$, siRNA treatment of Be(2)-M17 cells with FSK (50 $\mu \mathrm{M}, 60$ min) without pretreatment increases $(r f$ hnRNA eightfold, and this is reduced to fourfold by TGOT. The siRNA construct for CRTC3 reduces the Crf hnRNA response to FSK, and eliminates the inhibitory effect of TGOT. The control and CRTC2 oligo do not modify Crf hnRNA levels. Data represent mean + SEM relative to Crf hnRNA in untreated cells, which was similar to that found in cells treated with TGOT in the absence of FSK; dashed line indicates basal levels set to $1 ;{ }^{*} p<0.05$ versus TGOT ${ }^{-} / \mathrm{FSK}^{+} ; \# p<0.001$ versus untreated TGOT ${ }^{-} / \mathrm{FSK}^{+}, n=5-8$. B, ChIP incubation with FSK (50 $\mu \mathrm{M}, 10 \mathrm{~min}$ ) promotes the binding of CRTC2 to the Crf promoter, and this is not affected by TGOT. C, TGOT prevents the FSK-induced binding of CRTC3 to the Crf promoter. TGOT has no effects when applied alone in both experiments. Data represent mean fold-change in promoter occupancy relative to the $\mathrm{TGOT}^{-} / \mathrm{FSK}^{+}$group (set to 1$)+\mathrm{SEM} .{ }^{*} p<0.05$ versus $\mathrm{TGOT}^{-} / \mathrm{FSK}^{+}$group; $\# p<0.05$ versus $\mathrm{TGOT}^{-} / \mathrm{FSK}^{-}$group; $n=4$.

els, consistent with a previous report where OTR was detected in the PVN only following infusion of an OTR antagonist, suggesting that OTR expression is under negative control of its ligand (Freund-Mercier et al., 1994). Even the use of the reporter mice in our study could not reliably reveal the expression of OTRs in the PVN as previously described (Yoshida et al., 2009), although it is known from behavioral (this study; Blume et al., 2008; Jurek et al., 2012), physiological (Moos and Richard, 1989; Leng et al., 2008; Jurek et al., 2012; van den Burg et al., 2015), and molecular studies (Freund-Mercier et al., 1994; Dabrowska et al., 2011) that the OTR is expressed in the PVN. Consistent with this, a number of Crf cells are surrounded by OT-positive boutons, suggesting that these Crf cells express the OTR (Dabrowska et al., 2011). Moreover, Crf expression can be induced during stress in mag- nocellular neurons that are Crf-negative under control conditions (Kresse et al., 2001). This has been shown for stressors of a systemic nature, especially inflammation (Kresse et al., 2001) and adrenalectomy (Swanson et al., 1983). Thus, it is conceivable that the effects observed in vivo are mediated, at least in part, by a small number of OTRs expressed in Crf neurons, undetectable in the present experimental conditions.

On the other hand, it is also possible that the effects in vivo are indirect, mediated by OTR located in afferent projections to Crf neurons in the PVN. It has been shown that the inhibitory effect on Crf expression following intracerebroventricular administration of OT can be blocked by the $\mathrm{GABA}_{\mathrm{A}}$ receptor blocker bicuculline (Bülbül et al., 2011), suggesting a role for OT-sensitive inhibitory interneurons. However, this is unlikely because none 
of the OTR-expressing neurons in the PVN appear to be GABAergic (Dabrowska et al., 2013). Thus, although direct and indirect mechanisms may be involved, our data clearly demonstrate that OT administration alters the temporal dynamics of CRTC3 translocation, and subsequent $\mathrm{Crf}$ transcription under stress conditions; both in vivo and in vitro. Moreover, the ability of CRTC3 siRNA to block the effects of OT on Crf hnRNA in Be(2)-M17 cells indicates that the modulatory action of OT on Crf transcription involves the CRTC3 pathway.

A rather unexpected finding was that OT only influences the translocation of CRTC3 and not that of CRTC2. Although we did observe nuclear translocation of CRTC2 following 10 min of restraint, OT did not affect nuclear CRTC2 levels. Earlier studies have shown that, unlike CRTC1, both CRTC2 and CRTC3 control the transcription of the Crf gene (Liu et al., 2011, 2012). However, these studies focused on the recovery period of rats following $1 \mathrm{~h}$ of restraint stress, a stress-protocol that has been shown to reduce OTR content in the PVN of voles (Smith and Wang, 2013). This finding led us to study the effects of OT on Crf expression during a short acute stress paradigm, when the OTRs are still fully expressed and functional.

The actions of OT on cAMP/CREB-regulated Crfgene expression were limited to CRTC3 regulation, as shown by the lack of effect of OT on stress-induced CREB Ser133 phosphorylation. Both our in vivo and in vitro experiments showed a similar shortlived, stress- or FSK-induced increase of CREB phosphorylation in the absence, as well as in the presence, of OT or the specific OTR agonist TGOT. This is consistent with the notion that the actions of CRTCs are independent from the CREB Ser133 phosphorylation site (Takemori et al., 2007).

The lack of effect of OT on PCREB also makes the involvement of regulatory mechanisms related to CREB activity unlikely, such as competition of the inhibitory factor ICER with pCREB at the Crf promoter. Furthermore, ICER is G $\alpha$ s-cAMP activated, whereas the OTR is coupled to G $\alpha$ i and $\mathrm{G} \alpha \mathrm{q}$, with $\mathrm{PKC} / \mathrm{PLC} \beta$ as downstream effectors, rather than cAMP (Gimpl and Fahrenholz, 2001).

The intracellular signaling pathway that couples the OTR to CRTC3 is currently not known. A major protein kinase known to regulate CRTC phosphorylation and nuclear trafficking is saltinducible kinase (SIK; Sasaki et al., 2011; Clark et al., 2012). SIK is a member of the mammalian AMP-activated protein kinase (AMPK) family. AMPK is activated by OT in skeletal muscle cells (Lee et al., 2008; Florian et al., 2010), and it is thus possible that the OTR also activates SIK. Its two isoforms, SIK1 and SIK2, are present in hypothalamic neurons of the PVN and have been shown to inhibit $\mathrm{Cr} f$ transcription by impairing CRTC trafficking to the nucleus (Liu et al., 2011). An additional target of SIK1 may be the myocyte enhancer factor 2 (MEF2), which also has a binding site in the $\mathrm{Crf}$ promoter and regulates its gene transcription following activation by CaMKII, MEK1/2, ERK5/BMK, and p38 (Zhao et al., 1999; Lu et al., 2000; Flavell et al., 2006). These kinases are coupled to the OTR (this study; Devost et al., 2008; Kim et al., 2015), whereas other target genes of MEF2, such as RGS2 or PACAP (Flavell et al., 2008) have also been implicated in the anxiolytic effect of OT (Park et al., 2002; Okimoto et al., 2012), and regulation of Crf expression (Stroth and Eiden, 2010). Whether the OTR exclusively regulates the CRTC3 pathway via SIK1, or has also implications on the activity of MEF2, again via SIK1, to alter the expression of Crf and Crf-related proteins, remains to be elucidated.

In our study, acute synthetic OT exerts only a minor influence on acute HPA-axis activity, as it had only minimal effects on the increase of plasma ACTH during stress. It is thus unlikely that OT modulates Crf release, leaving the acute stress response intact. The observed actions of OT on Crf gene transcription during the early phase of the stress response might rather serve to reallocate energy away from costly investments like gene expression. Replenishment of depleted CRF stores (Aguilera and Liu, 2012) could be enhanced by OT later, as suggested by increased Crf transcription, at both the hnRNA and mRNA levels, and CRTC3 translocation at later time points in our in vitro studies. A repression of Crfgene transcription as part of a negative feedback mechanism is unlikely, because, in our protocols, OT is already high before the onset of the stressor (such as following successful mating in male rats; Waldherr and Neumann, 2007) and Crf transcription is only delayed, not repressed, over the whole $30 \mathrm{~min}$ period of restraint. Furthermore, there is no corticosterone in the cell culture medium that could be implicated in the effects of OT on the CRTC3-Crf expression pathway. However, the lack of negative feedback in vitro could account for the late $(4-6 \mathrm{~h})$ potentiation of FSK-induced $\mathrm{Cr} f$ gene transcription by TGOT in vitro.

Our study has revealed a novel, and specific, role for the CREB cofactor CRTC3 and is the first study that describes a clearly defined physiological role of CRTC3 in the brain; namely regulation of stress-induced $\mathrm{Crf}$ transcription. Importantly, CRTC3 is recruited during stress, but, in sharp contrast to CRTC2, its translocation from the cytosol to the nucleus is regulated by the OTR. This particular stress-CRTC3 pathway, which can be modulated by OT, may not be unique to the Crf gene alone, but to other CREB-regulated genes, such as Crfr $1 / 2$ and $C r f-b p$ as well. Thus, a further search for stress-related genes that are under the control of the OT-CRTC3 pathway seems warranted and might lead to a better understanding of the regulation of gene transcription during stress.

\section{References}

Aguilera G, Liu Y (2012) The molecular physiology of CRH neurons. Front Neuroendocrinol 33:67-84. CrossRef Medline

Assimacopoulos S, Grove EA, Ragsdale CW (2003) Identification of a Pax6dependent epidermal growth factor family signaling source at the lateral edge of the embryonic cerebral cortex. J Neurosci 23:6399-6403. Medline

Baird JP, Rios C, Loveland JL, Beck J, Tran A, Mahoney CE (2008) Effects of hindbrain melanin-concentrating hormone and neuropeptide $\mathrm{Y}$ administration on licking for water, saccharin, and sucrose solutions. Am J Physiol Regul Integr Comp Physiol 294:R329-343. CrossRef Medline

Blume A, Bosch OJ, Miklos S, Torner L, Wales L, Waldherr M, Neumann ID (2008) Oxytocin reduces anxiety via ERK1/2 activation: local effect within the rat hypothalamic paraventricular nucleus. Eur J Neurosci 27: 1947-1956. CrossRef Medline

Bonefeld BE, Elfving B, Wegener G (2008) Reference genes for normalization: a study of rat brain tissue. Synapse 62:302-309. CrossRef Medline

Bülbül M, Babygirija R, Cerjak D, Yoshimoto S, Ludwig K, Takahashi T (2011) Hypothalamic oxytocin attenuates CRF expression via GABA(A) receptors in rats. Brain Res 1387:39-45. CrossRef Medline

Clark K, MacKenzie KF, Petkevicius K, Kristariyanto Y, Zhang J, Choi HG, Peggie M, Plater L, Pedrioli PG, McIver E, Gray NS, Arthur JS, Cohen P (2012) Phosphorylation of CRTC3 by the salt-inducible kinases controls the interconversion of classically activated and regulatory macrophages. Proc Natl Acad Sci U S A 109:16986-16991. CrossRef Medline

Conkright MD, Canettieri G, Screaton R, Guzman E, Miraglia L, Hogenesch JB, Montminy M (2003) TORCs: transducers of regulated CREB activity. Mol Cell 12:413-423. CrossRef Medline

Dabrowska J, Hazra R, Ahern TH, Guo JD, McDonald AJ, Mascagni F, Muller JF, Young LJ, Rainnie DG (2011) Neuroanatomical evidence for reciprocal regulation of the corticotrophin-releasing factor and oxytocin systems in the hypothalamus and the bed nucleus of the stria terminalis of the rat: implications for balancing stress and affect. Psychoneuroendocrinology 36:1312-1326. CrossRef Medline 
Dabrowska J, Hazra R, Guo JD, Dewitt S, Rainnie DG (2013) Central CRF neurons are not created equal: phenotypic differences in CRF-containing neurons of the rat paraventricular hypothalamus and the bed nucleus of the stria terminalis. Front Neurosci 7:156. CrossRef Medline

Dalwadi DA, Uht RM (2013) Hypothalamic and amygdalar cell lines differ markedly in mitochondrial rather than nuclear encoded gene expression. BMC Genomics 14:413. CrossRef Medline

Devost D, Carrier ME, Zingg HH (2008) Oxytocin-induced activation of eukaryotic elongation factor 2 in myometrial cells is mediated by protein kinase C. Endocrinology 149:131-138. CrossRef Medline

Donaldson ZR, Young LJ (2008) Oxytocin, vasopressin, and the neurogenetics of sociality. Science 322:900-904. CrossRef Medline

Engelmann M, Ebner K, Landgraf R, Holsboer F, Wotjak CT (1999) Emotional stress triggers intrahypothalamic but not peripheral release of oxytocin in male rats. J Neuroendocrinol 11:867-872. CrossRef Medline

Flavell SW, Cowan CW, Kim TK, Greer PL, Lin Y, Paradis S, Griffith EC, Hu LS, Chen C, Greenberg ME (2006) Activity-dependent regulation of MEF2 transcription factors suppresses excitatory synapse number. Science 311:1008-1012. CrossRef Medline

Flavell SW, Kim TK, Gray JM, Harmin DA, Hemberg M, Hong EJ, Markenscoff-Papadimitriou E, Bear DM, Greenberg ME (2008) Genome-wide analysis of MEF2 transcriptional program reveals synaptic target genes and neuronal activity-dependent polyadenylation site selection. Neuron 60:1022-1038. CrossRef Medline

Florian M, Jankowski M, Gutkowska J (2010) Oxytocin increases glucose uptake in neonatal rat cardiomyocytes. Endocrinology 151:482-491. CrossRef Medline

Freund-Mercier MJ, Stoeckel ME, Klein MJ (1994) Oxytocin receptors on oxytocin neurones: histoautoradiographic detection in the lactating rat. J Physiol 480:155-161. CrossRef Medline

Gibbs DM, Vale W, Rivier J, Yen SS (1984) Oxytocin potentiates the ACTHreleasing activity of CRF(41) but not vasopressin. Life Sci 34:2245-2249. CrossRef Medline

Gimpl G, Fahrenholz F (2001) The oxytocin receptor system: structure, function, and regulation. Physiol Rev 81:629-683. Medline

Gray TS (1993) Amygdaloid CRF pathways. Role in autonomic, neuroendocrine, and behavioral responses to stress. Ann N Y Acad Sci 697:53-60. CrossRef Medline

Gray TS, Magnuson DJ (1992) Peptide immunoreactive neurons in the amygdala and the bed nucleus of the stria terminalis project to the midbrain central gray in the rat. Peptides 13:451-460. CrossRef Medline

Haubensak W, Kunwar PS, Cai H, Ciocchi S, Wall NR, Ponnusamy R, Biag J, Dong HW, Deisseroth K, Callaway EM, Fanselow MS, Lüthi A, Anderson DJ (2010) Genetic dissection of an amygdala microcircuit that gates conditioned fear. Nature 468:270-276. CrossRef Medline

Heo H, Yoo M, Han D, Cho Y, Joung I, Kwon YK (2013) Upregulation of TrkB by forskolin facilitated survival of MSC and functional recovery of memory deficient model rats. Biochem Biophys Res Commun 431:796801. CrossRef Medline

Hillerer KM, Reber SO, Neumann ID, Slattery DA (2011) Exposure to chronic pregnancy stress reverses peripartum-associated adaptations: implications for postpartum anxiety and mood disorders. Endocrinology 152:3930-3940. CrossRef Medline

Jurek B, Slattery DA, Maloumby R, Hillerer K, Koszinowski S, Neumann ID, van den Burg EH (2012) Differential contribution of hypothalamic MAPK activity to anxiety-like behaviour in virgin and lactating rats. PloS one 7:e37060. CrossRef Medline

Kim SH, MacIntyre DA, Firmino Da Silva M, Blanks AM, Lee YS, Thornton S, Bennett PR, Terzidou V (2015) Oxytocin activates NF-kappaBmediated inflammatory pathways in human gestational tissues. Mol Cell Endocrinol 403:64-77. CrossRef Medline

Kresse AE, Million M, Saperas E, Taché Y (2001) Colitis induces CRF expression in hypothalamic magnocellular neurons and blunts CRF gene response to stress in rats. Am J Physiol Gastrointest Liver Physiol 281: G1203-G1213. Medline

Lee ES, Uhm KO, Lee YM, Kwon J, Park SH, Soo KH (2008) Oxytocin stimulates glucose uptake in skeletal muscle cells through the calciumCaMKK-AMPK pathway. Regul Pept 151:71-74. CrossRef Medline

Leng G, Caquineau C, Ludwig M (2008) Priming in oxytocin cells and in gonadotrophs. Neurochem Res 33:668-677. CrossRef Medline

Liu Y, Aguilera G (2009) Cyclic AMP inducible early repressor mediates the termination of corticotropin releasing hormone transcription in hypothalamic neurons. Cell Mol Neurobiol 29:1275-1281. CrossRef Medline

Liu Y, Kamitakahara A, Kim AJ, Aguilera G (2008) Cyclic adenosine 3' , 5' monophosphate responsive element binding protein phosphorylation is required but not sufficient for activation of corticotropin-releasing hormone transcription. Endocrinology 149:3512-3520. CrossRef Medline

Liu Y, Knobloch HS, Grinevich V, Aguilera G (2011) Stress induces parallel changes in corticotrophin-releasing hormone $(\mathrm{CRH})$ transcription and nuclear translocation of transducer of regulated cAMP response elementbinding activity 2 in hypothalamic CRH neurones. J Neuroendocrinol 23:216-223. CrossRef Medline

Liu Y, Poon V, Sanchez-Watts G, Watts AG, Takemori H, Aguilera G (2012) Salt-inducible kinase is involved in the regulation of corticotropinreleasing hormone transcription in hypothalamic neurons in rats. Endocrinology 153:223-233. CrossRef Medline

Lu J, McKinsey TA, Nicol RL, Olson EN (2000) Signal-dependent activation of the MEF2 transcription factor by dissociation from histone deacetylases. Proc Natl Acad Sci U S A 97:4070-4075. CrossRef Medline

Lukas M, Toth I, Reber SO, Slattery DA, Veenema AH, Neumann ID (2011) The neuropeptide oxytocin facilitates pro-social behavior and prevents social avoidance in rats and mice. Neuropsychopharmacology 36:2159 2168. CrossRef Medline

Ma XM, Levy A, Lightman SL (1997) Rapid changes in heteronuclear RNA for corticotrophin-releasing hormone and arginine vasopressin in response to acute stress. J Endocrinol 152:81-89. CrossRef Medline

Manning M, Kruszynski M, Bankowski K, Olma A, Lammek B, Cheng LL, Klis WA, Seto J, Haldar J, Sawyer WH (1989) Solid-phase synthesis of 16 potent (selective and nonselective) in vivo antagonists of oxytocin. J Med Chem 32:382-391. CrossRef Medline

Manning M, Stoev S, Chini B, Durroux T, Mouillac B, Guillon G (2008) Peptide and non-peptide agonists and antagonists for the vasopressin and oxytocin V1a, V1b, V2 and OT receptors: research tools and potential therapeutic agents. Prog Brain Res 170:473-512. CrossRef Medline

Moos F, Richard P (1989) Paraventricular and supraoptic bursting oxytocin cells in rat are locally regulated by oxytocin and functionally related. J Physiol 408:1-18. CrossRef Medline

Mugele K, Kügler H, Spiess J (1993) Immortalization of a fetal rat brain cell line that expresses corticotropin-releasing factor mRNA. DNA Cell Biol 12:119-126. CrossRef Medline

Mulchahey JJ, Regmi A, Sheriff S, Balasubramaniam A, Kasckow JW (1999) Coordinate and divergent regulation of corticotropin-releasing factor (CRF) and CRF-binding protein expression in an immortalized amygdalar neuronal cell line. Endocrinology 140:251-259. CrossRef Medline

Neumann ID, Landgraf R (2012) Balance of brain oxytocin and vasopressin: implications for anxiety, depression, and social behaviors. Trends Neurosci 35:649-659. CrossRef Medline

Neumann ID, Torner L, Wigger A (2000a) Brain oxytocin: differential inhibition of neuroendocrine stress responses and anxiety-related behaviour in virgin, pregnant and lactating rats. Neuroscience 95:567-575. CrossRef Medline

Neumann ID, Wigger A, Torner L, Holsboer F, Landgraf R (2000b) Brain oxytocin inhibits basal and stress-induced activity of the hypothalamopituitary-adrenal axis in male and female rats: partial action within the paraventricular nucleus. J Neuroendocrinol 12:235-243. CrossRef Medline

Neumann I, Russell JA, Landgraf R (1993) Oxytocin and vasopressin release within the supraoptic and paraventricular nuclei of pregnant, parturient and lactating rats: a microdialysis study. Neuroscience 53:65-75. CrossRef Medline

Okimoto N, Bosch OJ, Slattery DA, Pflaum K, Matsushita H, Wei FY, Ohmori M, Nishiki T, Ohmori I, Hiramatsu Y, Matsui H, Neumann ID, Tomizawa K (2012) RGS2 mediates the anxiolytic effect of oxytocin. Brain Res 1453:26-33. CrossRef Medline

Ondrejcakova M, Bakos J, Garafova A, Kovacs L, Kvetnansky R, Jezova D (2010) Neuroendocrine and cardiovascular parameters during simulation of stress-induced rise in circulating oxytocin in the rat. Stress 13:314322. CrossRef Medline

Park ES, Echetebu CO, Soloff S, Soloff MS (2002) Oxytocin stimulation of RGS2 mRNA expression in cultured human myometrial cells. Am J Physiol Endocrinol Metab 282:E580-E584. CrossRef Medline

Paxinos G, Watson, CR (1998) The rat brain in stereotaxic coordinates (Ed 4). New York: Academic 
Petersson M, Hulting AL, Uvnäs-Moberg K (1999) Oxytocin causes a sustained decrease in plasma levels of corticosterone in rats. Neurosci Lett 264:41-44. CrossRef Medline

Roy C, Roy MC, Gauvreau D, Poulin AM, Tom FQ, Timofeeva E, Richard D, Cianflone K (2011) Acute injection of ASP in the third ventricle inhibits food intake and locomotor activity in rats. Am J Physiol Endocrinol Metab 301:E232-E241. CrossRef Medline

Sala C, Rudolph-Correia S, Sheng M (2000) Developmentally regulated NMDA receptor-dependent dephosphorylation of cAMP response element-binding protein (CREB) in hippocampal neurons. J Neurosci 20:3529-3536. Medline

Sasaki T, Takemori H, Yagita Y, Terasaki Y, Uebi T, Horike N, Takagi H, Susumu T, Teraoka H, Kusano K, Hatano O, Oyama N, Sugiyama Y, Sakoda S, Kitagawa K (2011) SIK2 is a key regulator for neuronal survival after ischemia via TORC1-CREB. Neuron 69:106-119. CrossRef Medline

Slattery DA, Neumann ID (2010) Chronic icv oxytocin attenuates the pathological high anxiety state of selectively bred Wistar rats. Neuropharmacology 58:56-61. CrossRef Medline

Smith AS, Wang Z (2014) Hypothalamic oxytocin mediates social buffering of the stress response. Biol Psychiatry 76:281-288. CrossRef Medline

Stroth N, Eiden LE (2010) Stress hormone synthesis in mouse hypothalamus and adrenal gland triggered by restraint is dependent on pituitary adenylate cyclase-activating polypeptide signaling. Neuroscience 165: 1025-1030. CrossRef Medline

Swanson LW, Sawchenko PE, Rivier J, Vale WW (1983) Organization of ovine corticotropin-releasing factor immunoreactive cells and fibers in the rat brain: an immunohistochemical study. Neuroendocrinology 36: 165-186. CrossRef Medline

Takemori H, Kanematsu M, Kajimura J, Hatano O, Katoh Y, Lin XZ, Min L, Yamazaki T, Doi J, Okamoto M (2007) Dephosphorylation of TORC initiates expression of the StAR gene. Mol Cell Endocrinol 265-266:196-204. Medline

Tomizawa K, Iga N, Lu YF, Moriwaki A, Matsushita M, Li ST, Miyamoto O, Itano T, Matsui H (2003) Oxytocin improves long-lasting spatial memory during motherhood through MAP kinase cascade. Nat Neurosci 6:384-390. CrossRef Medline

Toth I, Neumann ID, Slattery DA (2012) Central administration of oxytocin receptor ligands affects cued fear extinction in rats and mice in a timepointdependent manner. Psychopharmacology 223:149-158. CrossRef Medline

van den Burg EH, Stindl J, Grund T, Neumann ID, Strauss O (2015) Oxytocin stimulates extracellular Ca influx through TRPV2 channels in hypothalamic neurons to exert its anxiolytic effects. Neuropsychopharmacology. Advance online publication. Retrieved May 27, 2015. CrossRef Medline

Van Tol HH, Bolwerk EL, Liu B, Burbach JP (1988) Oxytocin and vasopressin gene expression in the hypothalamo-neurohypophyseal system of the rat during the estrous cycle, pregnancy, and lactation. Endocrinology 122:945-951. CrossRef Medline

Viviani D, Charlet A, van den Burg E, Robinet C, Hurni N, Abatis M, Magara F, Stoop R (2011) Oxytocin selectively gates fear responses through distinct outputs from the central amygdala. Science 333:104-107. CrossRef Medline

Waldherr M, Neumann ID (2007) Centrally released oxytocin mediates mating-induced anxiolysis in male rats. Proc Natl Acad Sci U S A 104: 16681-16684. CrossRef Medline

Watts AG, Sanchez-Watts G, Liu Y, Aguilera G (2011) The distribution of messenger RNAs encoding the three isoforms of the transducer of regulated cAMP responsive element binding protein activity in the rat forebrain. J Neuroendocrinol 23:754-766. CrossRef Medline

Windle RJ, Kershaw YM, Shanks N, Wood SA, Lightman SL, Ingram CD (2004) Oxytocin attenuates stress-induced c-fos mRNA expression in specific forebrain regions associated with modulation of hypothalamo-pituitary-adrenal activity. J Neurosci 24:2974-2982. CrossRef Medline

Yoshida M, Takayanagi Y, Inoue K, Kimura T, Young LJ, Onaka T, Nishimori K (2009) Evidence that oxytocin exerts anxiolytic effects via oxytocin receptor expressed in serotonergic neurons in mice. J Neurosci 29:22592271. CrossRef Medline

Zhao M, New L, Kravchenko VV, Kato Y, Gram H, di Padova F, Olson EN, Ulevitch RJ, Han J (1999) Regulation of the MEF2 family of transcription factors by p38. Mol Cell Biol 19:21-30. Medline

Zoicas I, Slattery DA, Neumann ID (2014) Brain oxytocin in social fear conditioning and its extinction: involvement of the lateral septum. Neuropsychopharmacology 39:3027-3035. CrossRef Medline 